\title{
Balya (Balıkesir) Pb-Zn Madeni Atık Sahasının Biyojeokimyası ve Asidik Maden Drenajı Oluşumuna Etkileri
}

Biogeochemistry of Ballkesir Balya Pb-Zn Mine Tailings Site and

Its Effect On Generation of Acid Mine Drainage

Nurgül ÇELIKK BALCI ${ }^{1}$, Serra GÜL ${ }^{1}$, Meryem Menekşe KILIÇ², Nevin Gül KARAGÜLER ${ }^{2}$, Erol SARI ${ }^{3}$, M. Şeref SÖNMEZ ${ }^{4}$

${ }^{I}$ İstanbul Teknik Üniversitesi Jeoloji Mühendisliği Bölümü, Ayazaga Kampüsü, 34469 Istanbul, (e-posta:ncelik@itu.edu.tr)

${ }^{2}$ Ístanbul Teknik Üniversitesi Moleküler Biyoloji ve Genetik Bölümü, Ayazaga Kampüsü, 34469 İstanbul 3.İstanbul Üniversitesi Deniz Bilimleri ve İşletmeciliği Enstitüsü, Vefa, İstanbul

${ }^{4}$ İstanbul Teknik Üniversitesi Malzeme ve Metalurji Mühendisliği Bölümü, Ayazaga Kampüsü, 34469

\section{ÖZ}

$\mathrm{Bu}$ çalı̧̧mada, Türkiye'nin en büyük ve en eski maden atık sahası Balıkesir Balya $\mathrm{Pb}$ - $\mathrm{Zn}$ maden atık sahasının biyojeokimyası ve asidik maden drenajı (AMD) oluşumuna etkileri jeokimyasal, moleküler ve mikrobiyolojik teknikler birlikte kullanılarak araştırılmıştır. Balya atık sahasında $\mathrm{Pb}-\mathrm{Zn}$ madencilik aktivitelerinden geride kalan sülfürce zengin pasaların/atıkların atmosferle teması sonucunda düşük pH'lı (2.7) ve yüksek metal içerikli (1.88 mg/L Pb, $24 \mathrm{mg} / \mathrm{L} \mathrm{Zn,} 2.5 \mathrm{mg} / \mathrm{L}$ As ve $17 \mathrm{mg} / \mathrm{L} \mathrm{Cu}$ ) asidik sularoluşarak ortamın kontamine olmasına neden olmaktadır. Maden atığ , sediman, asidik ve yüzey suyu örneklerinde gerçekleştirilen jeokimyasal ve mikrobiyolojik analizler çevre açısından zararlı metallerin taşınmasında ve dağılımında sülfürce zengin atıkların ayrışmasından kaynaklanan asidik suların (pH 2.7) birincil etken olduğunu göstermiştir. Balya atık sahasında gelişen ve asidik drenaj suyu içeren göletlerde gerçekleştirilen kultivasyon temelli mikrobiyoloji çalışması sonucunda asidik suların ortalama asidofilik sülfür oksitleyen (aSOB) ve asidofilik Fe oksitleyen bakteri (aFeOB) miktarları sirası ile $8.4 \times 10^{8} \mathrm{cell} /$ $\mathrm{ml}$ ve $9.6 \times 10^{7}$ cell/ $/ \mathrm{ml}$ 'dir. Aynı değerler, atıkların ulaştığı Maden deresi yüzey su örneklerinde $3.8 \times 10^{6}$ cell $/ \mathrm{ml}$ ve $5.7 \times 10^{3} \mathrm{cell} / \mathrm{ml}$ olarak asidik sulara oranla daha düşük saptanmıştır. Maden deresi ve asidik gölet sedimanları üzerinde gerçekleştirilen 16S rDNA dizi analizine göre Balya atık sahasında Fe ve $\mathrm{S}$ döngüsünde Acidithiobacillus spp. grubuna bağlı prokaryotların dominant olduğu ortaya konmuştur. Bunun yanısıra, daha az oranda S oksidasyonunda etkili Sulfobacillus spp. populasyonuda tespit edilmiştir. Ayrıca, asidik suların ve atıkların ulaştı̆̆ daha düşük asidik karakter gösteren Maden Deresi sediman örneklerinde indirgenmiş sülfür türlerini (örn. kükürt) oksitleyen Thiobacillus spp. ve Thiovirga spp. cinsine bağlı mikroorganizmalar tespit edilmiştir. Bu türlerin tespiti, sahada değişen jeokimyasal 
koşullara uyum sağlayan dinamik bir mikrobiyal topluluğu göstermektedir. Sahada Fe oksitleyen ve indirgeyen mikroorganizmaların tespiti ile asidik sedimanlarda jarosit, plumbojarosit ve götit gibi ikincil Fe minerallerinin varlığı atıklardan metallerin salınımında, taşınımında ve depolanmasında mikrobiyal Fe döngüsünün önemli olduğunu göstermektedir. Tüm bu sonuçlar, Balya $\mathrm{Pb}-\mathrm{Zn}$ maden atık sahasında $\mathrm{S}$ ve Fe döngüsünde etkili mikroorganizmaların asidik suların oluşumunda ve bileşiminde ana rol oynadıklarını ortaya koymaktadır.

Anahtar Kelimeler: Balya Pb-Zn Madeni atık Sahası, Biyojeokimya, Mikroorganizma, Pirit.

\section{ABSTRACT}

Biogeochemical characteristsics of Ballkesir-Balya Pb-Zn Mine Waste site, known as the oldest and largest mine tailing site in Turkey, and its influence on generation of acid mine drainage was investigated by geochemical, molecular and microbiological approach. The oxidation of sulfide rich rocks and waste, mostly left over from Balya Pb-Zn mining activities, is generating acidic water with low $\mathrm{pH}$ (2.7), and contributing to metal contamination containing up to $1.88 \mathrm{mg} / \mathrm{L} \mathrm{Pb}, 24 \mathrm{mg} / \mathrm{L} \mathrm{Zn,} 2.5 \mathrm{mg} / \mathrm{L}$ As ve $17 \mathrm{mg} / \mathrm{L}$ $\mathrm{Cu}$. Geochemical and molecular/microbiological analysis on mine waste, sediment and water samples (acidic, surface) show that acidic surface waters generated from sulfide weathering are principal pathways for mobility and redistribution of environmentally important elements into the environments. Based on cultivation based microbiological analysis carried out on acidic ponds developed around and in Balya Mine waste sites, the mean acidofilic sulfur oxidizing bacteria (aSOB) and acidophilic iron oxidizing bacteria were determined as $8.4 \times 10^{8} \mathrm{cell} / \mathrm{ml}$ ve $9.6 \times 10^{7} \mathrm{cell} / \mathrm{ml}$, respectively. The relatively low values for surface water of Maden creek, where mine wastes reach, were determined as $3.8 \times 10^{6} \mathrm{cell} / \mathrm{ml}$ ve $5.7 \times 10^{3}$ cell/ml, respectively. Molecular analysis of $16 \mathrm{~S}$ rDNA gene sequences from acidic sediment and sediment from Maden Creek show the dominance of $S$ and Fe-oxidizing prokaryotes belonging to Acidithiobacillus spp. genus in the primary drainage communities. Relatively small populations of Sulfobacillus spp.were also determined. Moreover, species belong to Thiobacillus spp.and Thiovirga spp. genus were only determined on the sediment samples from Maden creek with low acidity relative to acidic sediment. These sulfur oxidizer indicates a dynamic microbial population which adapt to changing geochemical conditions. Identification of Fe oxidizer and reducer along with Jarosite, plumbojarosite and goethite in the sediments of acidic ponds indicate significance of microbial Fe cycle governing mobilization and redistribution of the metals in the waste site. Overall, it is shown that microorganisms regulating $S$ and Fe cycle in Balya mine waste site is the key factors controlling generation and chemistry of acidic drainage water.

Key Words: Balya Pb-Zn Mine Waste Site, Biogeochemistry, Microorganims, Pyrite

\section{GİRIŞ}

Doğada yaygın olarak bulunan metal sülfür mineralleri, yüzey/yeraltı madencilk aktiviteleri sırasında parçalanıp ufalandığından atmosferik oksijen ve su ile olan teması artar ve oksitlenmeye başlarlar. Kompleks biyo/ jeokimyasal reaksiyonların gerçekleştiği bu oksidasyon işlemleri sonrasında, yüksek sülfat ve metal içerikli, düşük pH'lı Asidik Maden drenaj1 (AMD) olarak isimlendirilen jeokimyasal oluşumlar meydana gelir. Doğada kendiliğinden oluştuğu gibi, madencilik aktiviteleri sırasında 
ve/veya sonrasında hızlanan bu oluşumların en önemli karakteristiği çözünmüş maddelerce (100$100.000 \mathrm{mg} / \mathrm{L})$ ve metallerce $(\mathrm{Cu}, \mathrm{Cd}, \mathrm{Pb}, \mathrm{Ni}, \mathrm{As}$, $\mathrm{Zn}, \mathrm{Fe}, \mathrm{Mn}, \mathrm{Al}$ vb.) zengin sular içermeleridir (Singer ve Stumm, 1970; Schippers vd., 1996, 1999, 2000, 2004; Nordstrom ve Alpers, 1999; Nordstrom vd., 2000; Balcı, 2010). Özellikle toksik metaller açışından zengin bu asidik sular, yüzey ve yeraltı sularına karışarak ekolojik hayat için tehdit oluşturmakta; kimi zamansa hayatı yok etmektedir.

AMD'nın oluşumu fiziksel, kimyasal ve biyolojik prosesleri içeren kompleks jeokimyasal süreçler içermektedir. AMD'nın başlamasında, oluşmasında ve devam etmesinde ana rolü oynayan metal sülfür minerali çoğunlukla pirittir (Taylor ve Wheeler, 1994; Nordstrom ve Alpers, 1999; Edwards vd., 2001, Balcı vd., 2007). Doğada, piritin ana oksitleyicileri moleküler oksijen $\left(\mathrm{O}_{2}\right)$ ve Fe(III) iyonudur. Düşük pH $(<3)$ ortamlarında piritin $\mathrm{Fe}(\mathrm{III})_{\mathrm{aq}}$ tarafindan kimyasal olarak oksitlenme oran1, $\mathrm{O}_{2}$ ile oksitlenme oranından 10-100 kat daha hizlidir (Nordstrom ve Alpers, 1999; Balcı vd.,2007). Dolayısıyla, asidik drenaj sularının oluşmasında Fe(III) aq iyonu önemli bir rol oynamaktadır. Asit maden sahalarında Fe(III) aq 'ün ana kaynağı pirittir. Piritin ayrışması ile ortama salınan Fe(II)'nin oksitlenerek Fe(III)'e dönüşüm hızı düşük pH koşullarında ( $\mathrm{pH}<3.5$ ) oldukça yavaştır (Stumm ve Morgan, 1981). Ancak, bazı asidofilik bakteri ve arkealar asidik ortamlarda $\mathrm{Fe}$ (II) aq 'nin $\mathrm{Fe}(\mathrm{III})_{\text {aq }}$ 'e oksitlenmesini hizlandirarak, $\mathrm{Fe}(\mathrm{III})_{\mathrm{aq}}$ iyonunun ortama salınımını sağlarlar. Bu nedenle, hem Fe hem de S oksitleyen prokaryotlar AMD'ı oluşumunda ve oluşumunun hızlanmasında önemli rol oynarlar (Blowes vd., 1998; Baker ve Banfield, 2003; Johnson ve Hallberg, 2003, Balc1 vd., 2007, 2006; Gül,2014).). Son y1llarda, asit maden sahalarında (AMS) yapılan moleküler ekoloji çalışmaları ile düşük $\mathrm{pH}$, yüksek sülfat ve metal konsantrasyonuna rağmen, bu ortamlarda değişik birçok mikroorganizma türü tespit edilmiştir $\mathrm{Bu}$ mikroorganizmalar, yüzey koşullarında sülfür mineralleri ile atmosferden elde edilen $\mathrm{CO}_{2}$, $\mathrm{O}_{2}, \mathrm{~N}_{2}$ ve kayaç-su etkileşimi sonucu ortama salınan fosfat arasındaki elektron akışına dayanan kemoototrofik temelli bir biyosfer oluştururlar (Silverman ve Lundgren, 1959; Garrels ve Thompson, 1960; Simmer ve Stumm, 1970; Sweerts vd.,1990; Suzuki ve Chan, 1994; Taylor ve Wheeler, 1994; Nordstrom ve Alpers, 1999). Daha önce yapılan birçok arazi ve laboratuar çalışmalarında mikroorganizmaların katalize ettiği sülfür oksidasyon oranlarının, kimyasal eşleniklerine göre çok daha yüsek olduğu tespit edilmiştir (Nordstrom ve Southam, 1997; Balc1 vd., 2007, 2012).

Sülfürlü maden atıklarında ki biyojeokimyasal prosesleri katalize eden mikroorganizmaların tanımlanması, mikrobiyal toplulukların analiz edilmesine ve ne tür mikroorganizmaların hangi süreçlerden sorumlu olduklarının anlaşılmasına, atık alanlarındaki yüksek ve düşük mikrobiyal aktivite bölgelerinin tespit edilmesine olanak sağlayacağı gibi, pirit ve Fe oksidasyonu gibi AMS'nın oluşmasında etkili reaksiyonların kinetiği konusunda da önemli veriler üretecektir. Başarılı bir AMD rehabilitasyon stratejisinin oluşturulması ve uygulanabilmesi için ilgili sahalarda mikrobiyal izleme çalışmalarının yürütülmesi şarttır.

Çalışmaya konu olan Balya $\mathrm{Pb}-\mathrm{Zn}$ Maden atık sahası, bölgede ki en büyük atık sahası olmasına karşın, sahanın biyojeokimyasal özellikleri ile metallerin taşınma proseslerine ve AMD'1 oluşumuna etkileri konusunda literatürde bilgi bulunmamaktadır. Sahada sinırlı sayıda yapılan araştırmalarda, ağır metal kaynağı olarak Balya $\mathrm{Pb}-\mathrm{Zn}$ sahası atıkları gösterilmiş, ancak, 
sahadaki sülfürlerin oksidasyon şekli (biyolojik ve/veya kimyasal) ve sahanın mikrobiyolojik topluluğunun bu süreçlere etkileri belirlenmemiştir (Aykol vd., 2002). Metallerin taşınım şekillerinin ve biyojeokimyasal süreçlerin bunlara etkisinin ortaya konması atık sahası civarındaki sulak alanlar için potansiyel kirleticilerin belirlenmesi bakımından gereklidir. $\mathrm{Bu}$ amaçla, $\mathrm{Pb}-\mathrm{Zn}$ atık sahasında mikrobiyolojik, jeokimyasal ve jeomikrobiyolojik çalışmalar yürütülerek AMD'1 oluşumunu kontrol eden biyo/jeokimyasal süreçler ve oluşan asidik suların çevreye olan etkileri multidisipliner bir yaklaşımla bu çalışma kapsamında ilk defa araştırılmıştır.

\section{ÇALIŞMA ALANI ve ÖZELLİKLERİ}

Balya $\mathrm{Pb}-\mathrm{Zn}$ maden yatağı ve maden atıkları, Marmara Bölgesi'nde Balıkesir il merkezinin yaklaşık $50 \mathrm{~km}$ kuzeybatısında yer almaktadır (Şekil 1). Maden atıklarını da kapsayan Balya ve çevresi Kocaçay boyunca dik vadilerle ayrılmıştır. Maden atıklarının yer aldığı sahanın yükseltisi yaklaşık 400-500 m arasında değişmektedir. Maden atık sahasının yakınından geçen Kocaçay ilçenin en büyük akarsuyudur. Çalışma alanı Balya ve civarında yazları sıcak ve kurak, kışları ise soğuk ve yağışlı bir iklim hakimdir. Balya ve civarının temel ekonomisini tarım ve hayvancılık oluşturmasına rağmen; madencilik ilk yerleşimlerden itibaren ilçenin önemli geçim kaynağ1 olmuştur. Antik dönemlerde de işletilen Balya $\mathrm{Pb}-\mathrm{Zn}$ maden yatağı Osmanlı döneminde (1839) ve sonrasındayabancı sermayeli şirketlerce 1939 yılına kadar işletilmiştir. Bu işletmelerden arta kalan maden ve atıkların yeniden işletmesine yönelik çalışmalar 1997 yılına kadar sürmüştür (Akyol, 1978). Son dönemde Balya sahasında yeni maden arama çalışmaları ve var olan atıkların yeniden değerlendirilmesi çalışmaları sürmektedir.
Çalışma sahasında temelde Permiyen yaşlı allokton kireçtaşları ve temel kayası üzerine uyumsuzlukla Triyas yaşı1 kiltaşı, kumtaşı, kireçtaşı ve çakı1 taşlarından oluşan seri (Karakaya Formasyonu) geldiği belirtilmiştir (Akyol, 1980). Permiyen kireçtaşları, Triyas yaşlı Karakaya formasyonu içerisinde olistoitler şeklinde bulunmaktadır. Balya $\mathrm{Pb}-\mathrm{Zn}$ cevher oluşumunun genellikle dasit-kireçtaşı dokanağında kontakt pirometasomatik ve kireçtaşının çatlaklarında hidrotermal damar türünde geliştiği ortaya konmuştur (Akyol, 1982; Aygen, 1956). Cevherleşmeler dasit, dasit porfiri ve mikrodiyorit türü kayaçlar içerisinde yer almaktadır (Özışık, 2013). Cevherleşmeler, dasit çatlaklarında realgar, orpiment, galenit, sfalerit ve pirit; kireçtaşının çatlaklarında ise galenit, sfalerit, antimonit, pirit, realgar ve orpiment birlikteliklerinden oluşmaktadır (Agdemir vd., 1994). Genel olarak cevher mineralleri pirit, markazit, sfalerit, galen, kalkopirit ve arsenopiritten oluşmaktadır. Akyol (1982), Balya maden yatağının rezervini 4.4 milyon ton olarak cevherin içeriğini ise \% 2.7 $\mathrm{Pb}, \%$ 7.2 $\mathrm{Zn}$ ve \% $0.3 \mathrm{Cu}$ olarak belirtmiştir. $\mathrm{Bu}$ cevher minerallerinin yanı sira daha az oranda markazit, bizmut, sülfat tuzları, bornit, arjenit, tetrahedrit, hematit, piroluzit, orpiment, realgar bulunduğu belirtilmiştir (Kovenko, 1940; Akyol, 1982).

Balya maden atık sahasında, daha önce çıkarılmış, kısmen cevher hazırlama işlemlerine tabii tutulmuş işletme atıkları, ocaklardan çıkarılmış olan düşük tenörlü, işlenmemiş cevher ve pasalar yamaçlara ve dere kenarlarına dökülmüştür (Şekil 2e,f). Bugün, Balya ve çevresinde 300.000 ton izabe cürufu (Şekil 2d), ve 1.200.000 ton flotasyon atığı (Şekil 2a,b,c). ve jig artığ olmak üzere toplam 1.500.000 ton kadar atık bulunduğu öngörülmektedir (Öngür, 2003; MTA, 1984; Akyol,1978). 


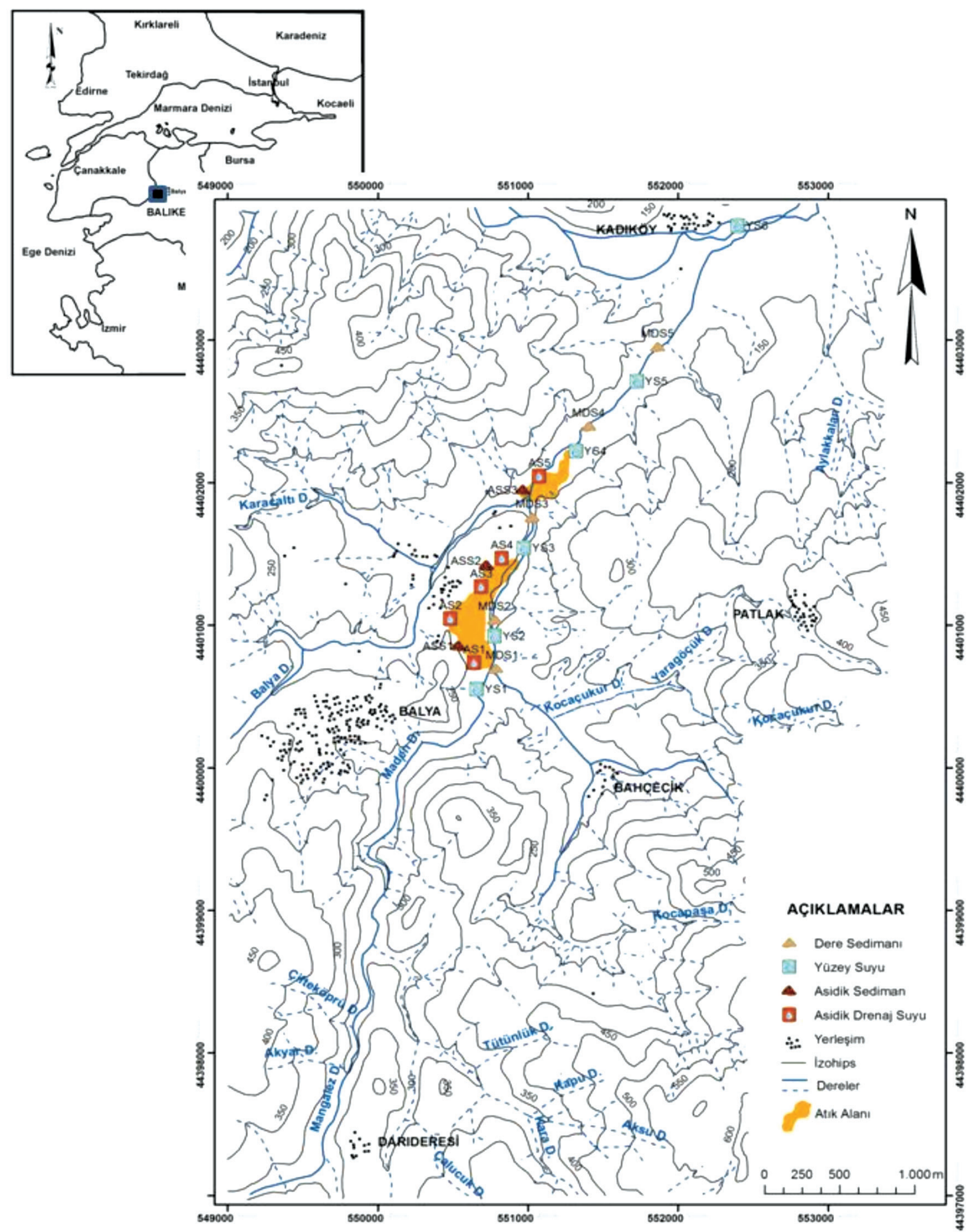

Şekil 1. Çalışma alanının konumu ve örnek lokasyon haritası

Figure 1. Location of the study area and sampled sites. 


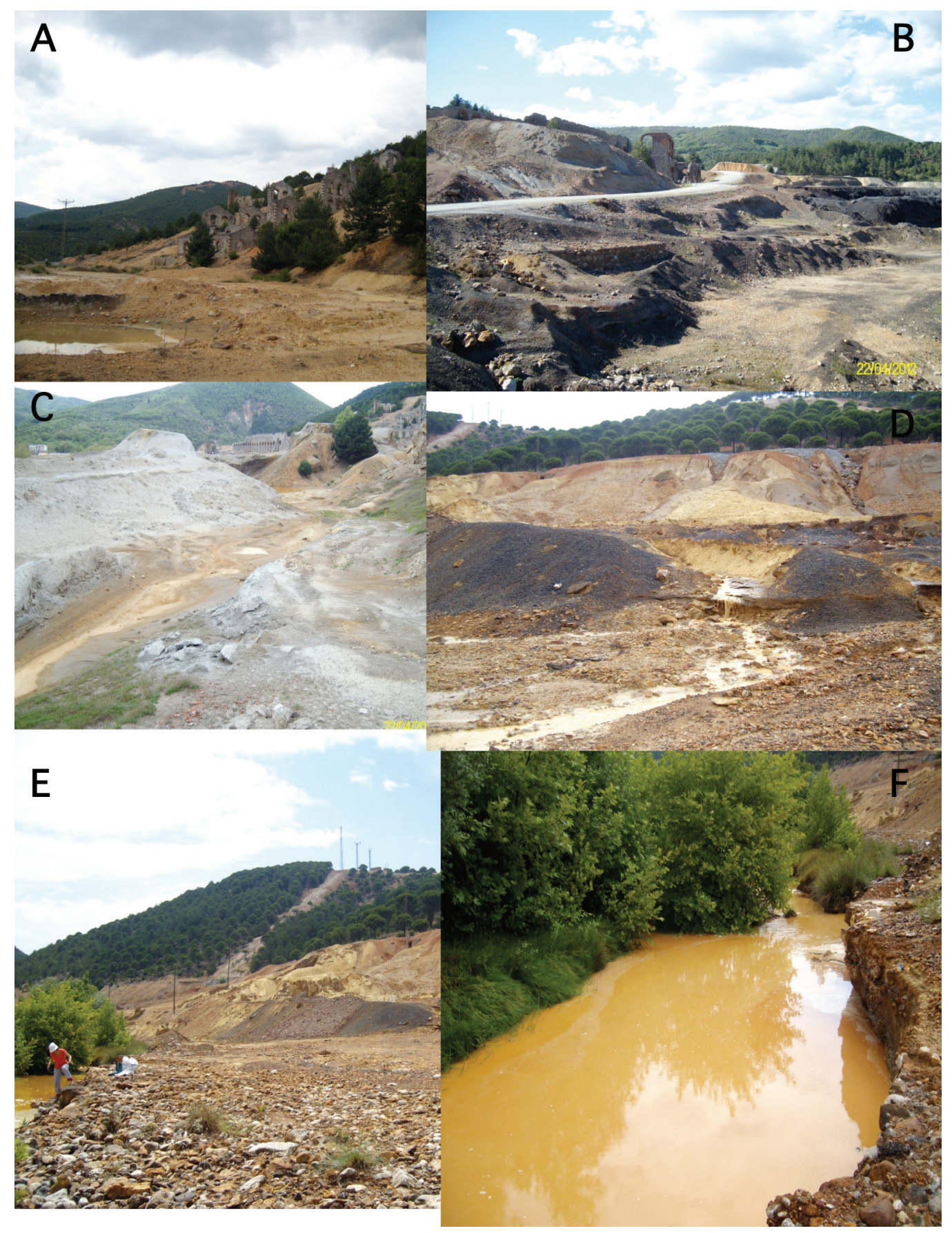

Şekil 2. Balya $\mathrm{Pb}-\mathrm{Zn}$ maden atıklarından görüntüler $\mathrm{A}$, Flotasyon atıkları; $\mathrm{B}$, Balya $\mathrm{Pb}-\mathrm{Zn}$ flotasyon ve izabe atıkları; C, Balya Pb-Zn flotasyon atığı; D,Flotasyon atıklarının yağmurlarla etrafa taşınması; E, Ocaklardan çıkarılmış olan düşük tenörlü, işlenmemiş cevher ve yantaşlar; F, Atıkların içinden geçen Maden Deresi ve derede oluşan renk değişimi

Figure 2. Photographs of features related to Balya Pb-Zn mine tailing sites A, View to flotation wastes; B, View to flotation and smelter wastes; $C$, View to flotation wastes; D, Dispersing of flotation waste via rain; E, View to Sulfide rich debris and ores with low tenor; F, View to Maden Creek crossing the mine tailings and colored development in the creek. 


\section{MATERYEL ve METOD}

\section{Asidik Maden Drenaji ve Yüzey Su Örneklemeleri}

Balya Pb-Znatıklarının etrafında oluşan asidik sular ile atık sahasından geçen Maden deresi üzerinde yağmur sonrasını takiben Nisan 2012 tarihinde su örnekleme çalışmaları gerçekleştirilmiştir (Şekil 1). Atıkların etrafinda oluşan asidik maden drenajından 5 adet asidik su (AS1-5) örneği, Maden deresi üzerinde ise 6 ayrı noktadan yüzey su (YS) örneği alınmıştır (Şekil 3a,b,c,d). Asidik ve yüzey sularının fiziksel parametreleri $(\mathrm{pH}$, sıcaklık, elektriksel iletkenlik ve yükseltgenmeindirgenme potansiyeli) taşınabilir cihazla yerinde ölçülmüştür (Şekil 3a). Su örnekleri yerinde 0,2 $\mu \mathrm{m}$ filtreden geçirilerek alınmış, 50 ve $100 \mathrm{~mL}$ 'lik polietilen şişelerde $+4^{\circ} \mathrm{C}$ 'de portatif buzluklarda muhafaza edilmiştir. Filtre edilen örneklerin 10 ml'sinde spektrofotometre cihazı ve Ferrozin metodu kullanılarak yerinde $\mathrm{Fe}(\mathrm{II})_{\mathrm{aq}}$ ve $\mathrm{Fe}_{\text {tot }}$ ölçümleri gerçekleştirilmiştir. Katyon ve element analizleri için $50 \mathrm{~mL}$ örnekleme yapılmış ve \% 5'lik $\mathrm{HNO}_{3}$ asit kullanılarak örneğin pH's1 2'ye kadar düşürülmüştür. Örnekler analiz edilene kadar $+4^{\circ} \mathrm{C}$ 'de ağzı kapalı olarak muhafaza edilmiştir. Katyon ve element analizleri İTÜ Adnan Tekin Araştırma ve Uygulama Merkezi'nde ICP-MS (endüktif eşlenik plazma - kütle spektrometresi) yöntemi ile analiz edilmiştir. Anyon analizleri $\left(\mathrm{Cl}, \mathrm{SO}_{4}, \mathrm{NO}_{3}\right)$ asit eklenmeyen $100 \mathrm{~mL}$ örnek kullanılarak İTÜ Jeomikrobiyoloji Laboratuarında spektrofotometrik olarak gerçekleştirilmiştir.

\section{Maden atık ve sediman örneklemeleri}

Çalışma alanındaki atıkların jeokimyasal karakterizasyonu için, sahadaki atıklardan toplam 5 adet örnekleme yapılmıştır. Atıkların etrafında gelişen asidik su göletlerinden toplam 3 adet (ASS1-ASS3), atıkların ulaştığı Maden deresinden ise toplam 5 adet sediman örneklemesi (MDS1MDS5) gerçekleştirilmiştir (Şekil 1). Dereden sediman örneklemeleri, burgu yardımı ile $20 \mathrm{~cm}$ derinliğinde yaklaşı $2.5 \mathrm{~kg}$ sediman örneği alımı şeklinde gerçekleştirilmiştir. Asidik göletlerden elde edilen çökel örnekleri ağırlıklı olarak ince bir tabaka halinde çökelen kırmızı renkli Fe-oksi/ hidroksitleri içermektedir (Şekil 3a, b c,d). Tüm katı (sediman, maden atığı) örneklerindeki majör ve iz element analizleri İTÜ Adnan Tekin Uygulama ve Araştırma merkezinde gerçekleştirilmiştir. $\mathrm{Bu}$ amaçla, katı örnekler $60^{\circ} \mathrm{C}$ 'de kurutulduktan sonra $63 \mu \mathrm{m}$ boyutuna öğütülmüştür. Ögütülüp hazırlanan 1 gr örnek $6 \mathrm{~mL} \mathrm{HF} \mathrm{( \% 40),3} \mathrm{ml} \mathrm{HCl}$ (\%37) ve $\mathrm{HNO}_{3}(\% 67)$ asit çözeltisinde çözülmüş, tekrar filtre edildikten sonra saf su ile $100 \mathrm{~mL}$ 'ye tamamlanarak ICP-MS ile analiz edilmiştir. Maden atıkları ile asidik çökeller üzerinde mineralojik çalışmalar XRD ile gerçekleştirilmiştir.

\section{Sedimentte Organik karbon analizi}

Ortamdaki (dere yatağı, atık sahası vb.,) organik karbon miktarı, gelişebilecek biyojeokimyasal reaksiyonlar ve türleri için belirleyici faktörlerden biridir. Bu nedenle, asidik çökel örneklerinde (asidik ASS1-ASS3; MDS1-MDS5) Walkley ve Black metodu kullanılarak (Gaudette vd., 1974) organik karbon analizi yapılmıştır. Bu amaçla, örnekler $105^{\circ} \mathrm{C}$ de kurutularak öğütülmüş ve her bir örnekden yaklaşık 0.5 gr alınarak üzerine 10 $\mathrm{ml}$ potasyum dikromat solüsyonu ilave edilip iyice karıştırılmıştır. Ardından, numuneye $20 \mathrm{ml}$ konsantirik sülfirik asit ilave edilerek 20-30 dakika karıştırılıp $200 \mathrm{ml}$ distile su ile seyreltildikten sonra $10 \mathrm{ml}$ fosforik asit $0,2 \mathrm{gr}$ sodyum florid ve $1 \mathrm{ml}$ difenilamin eklenmiştir. Daha sonra örnek titrasyona tabi tutulmuş ve titrasyon yeşil rengin açığa çıkmasıyla sona erdirilmiştir. 
Organik madde miktarı:

$\mathbf{C}_{\text {org }}=3.951 / \mathrm{g}(\mathbf{1}-\mathbf{T} / \mathrm{S})$ formülü kullanılarak

(\%) cinsinden hesaplanmıştır.

$\mathrm{g}=$ örneğin ağırlı̆̆ 1 (gr),

$\mathrm{T}=\mathrm{ml}$ demir çözeltisi örnek titrasyonu,

$\mathrm{S}=\mathrm{ml}$ demir çözeltisi blank titrasyonu.

\section{Mikrobiyolojik Çalışmalar}

Maden atık sahasındaki mikrobiyolojik topluluğu belirlemek amaciyla kultivasyon ve moleküler biyoloji teknikleri birlikte kullanılmıştır: 1-Atık sahasında Sülfür ve Demir döngüsünde aktif olan mikrobiyal türler ve miktarlarını belirlemek amacı ile En Muhtemel Sayı (Most probable number (MPN)) kultivasyon tekniği 2-Atık sahasının genel mikrobiyal topluluğunu belirlemek için 16S rDNA Moleküler biyoloji tekniği kullanılmıştır.

\section{En Muhtemel Sayı (Most Probable Number) Tekniği}

$\mathrm{Bu}$ teknik aktif /canlı mikroorganizmaların tayini için sıklıkla kullanılan bir yöntemdir. EMS tekniği kullanılarak, atıkların çevresinde oluşan asidik maden drenaji ile Maden Deresinde asidofilik Sülfür oksitleyen bakteri (aSOB), demir oksitleyen bakteri (FeOB) ile asidofilik demir indirgeyen bakteri (aFeIB) tayinleri yapılmıştır. Bakteri tayinlerinde, saptanmak istenen bakteri türüne uygun olarak önceden hazırlanan besiyerleri içeren ve steril hale getirilen aerobik kültür tüpleri $(9 \mathrm{ml})$ ve anaerobik serum şişeleri (9 ml) kullanılmıştır. Araziye getirilen kültür tüpleri ve serum şişeleri her bir örnekleme noktasında steril pipet uçları kullanılarak istenen su örneği ile inoküle edilmiştir. Inokülasyonda 5 tüp teknigi (Cochran, 1950) kullanılmıştır. Hazırlanan tüp ve serum şişeleri oda sıcaklığında $\left(25^{\circ} \mathrm{C} \pm 2\right)$ 4 hafta süreyle inkübe edilmiştir. Söz konusu mikroorganizmaların büyütülmesi için gerekli besiyeri ile pozitif tüplerin tanınması için önceki çalışmalarda başarıyla uygulanan yöntemler kullanılmıştır (Balcı vd., 2009, 2012 ; Hulshof vd., 2006 ve Benner vd., 2000).

\section{$16 S$ rDNA Methodu ile mikrobiyal topluluğun belirlenmesi}

Atık sahası içerisindeki farklı asidik maden drenaji göletlerinden 3 adeti (AS1-AS3) ve atıkların dereye ulaştığ1 noktadan alınan sediman örneklerinden 4 adeti (MDS1-MDS4) bu analizler için kullanılmıştır. Söz konusu sediman örnek alımları için, daha önce otoklav kullanılarak (humitsu -120 ${ }^{\circ} \mathrm{C}$ ve 1 kbar basınç) steril hale getirilmiş spatula ve $50 \mathrm{ml}$ steril santrifüj tüpleri kulllanılmıştır (Şekil 3e, f). Sediman örnekleri steril spatula kullanılarak, $50 \mathrm{ml}$ santrifüj tüpleri içerisine toplanmış bunu takiben tüplerin ağıları sıkıca kapatılarak kilitli torbalar içine yerleştirilmiştir. Örnekler, moleküler biyoloji analizine kadar geçen sürede $-21{ }^{\circ} C^{\prime}$ de saklanmıştır. Sediman örneklerinden (2-5 gr) yüksek verimde genomik DNA (gDNA) izolasyonu için FastPrep DNA ektraksiyon kiti kullanılmıştır. Kit kullanılarak elde edilen DNA çözeltisi, sonraki moleküler analizlere kadar $-21^{\circ} \mathrm{C}$ 'de saklanmıştır. Sediman örneklerinden elde edilen DNA çözeltisi üzerinde $16 \mathrm{~S}$ rDNA bölgesinden seçilmiş pA-F (5'-AGAGTTTGATCCTGGCTCAG-3') ve pH-R (5' AAGGAGGTGATCCAGCCGCA-3') primer çifti kullanarak polimeraz zincir reaksiyonu (PZR) gerçekleştirilmiştir. PZR reaktifleri, $(25 \mu \mathrm{L}) 1 \mathrm{X}$ PCR tamponu, $200 \mathrm{mM}$ dNTP (deoksinükleosid trifosfat), $0.25 \mathrm{mM}$ ileri ve geri primerler, 0.5 U Taq polimerazı ve $1 \mathrm{ml}$ DNA çözeltisinden oluşmaktadır. PZR aşamasından sonra, agaroz jel üzerinde PZR ürünlerinin kontrolü yapılmış ve uygun klonlama yöntemi kullanılarak (TOPO TA ${ }^{\circledR}$ Cloning Kit, Invitrogen) vektöre aktarılmış plazmidler, transformasyon sonrası uygun konakçı hücreye aktarılarak katı besiyerinde geliştirilmiştir. 
İlgilenilen PZR ürününün vektörde olduğunu gösteren agar besiyeri üzerindeki beyaz koloniler mavi/beyaz tarama yöntemi ile seçilmiştir. Seçilen beyaz koloniler sıvı besiyerinde büyütülmüş ve plazmid DNA örnekleri izole edilmiştir. ABI Prism 3100 Avant Automated Sequencer cihazının kullanılması ile herbir farklı mikroorganizmaya karşılık gelen DNA dizileri 2 yönlü M13 primer kullanılarak analiz edilmiştir. Tanımlanan dizi analizlerinin NCBI BLAST yardımı ile 16S rDNA dizi analizlerinin karşılaştırılması sonucunda diziler arasındaki farklılıklardan yararlanılarak cins ve tür düzeyinde hangi mikroorganizmaların bulunduğu tesbit edilmiştir.

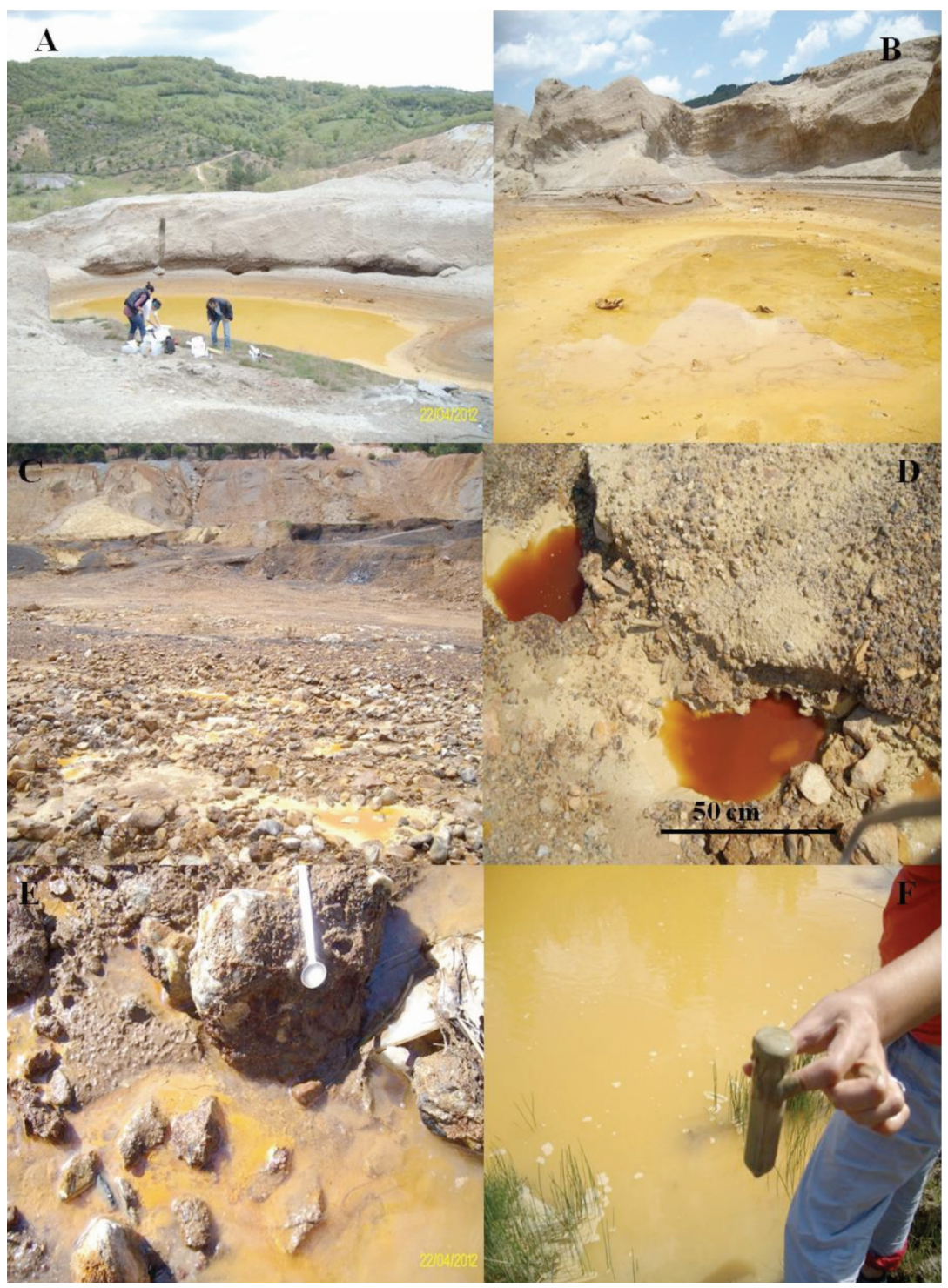

Şekil 3. A ve B: Atıkların üzerinde oluşan asidik göletler ve yapılan örnekleme çalışmalarından görüntü; C ve D: Flotasyon ve izabe atıkları içinde oluşan asidik göletler; Eve F, Asidik göletlerden mikrobiyolojik çalışmalar için örnek alımı.

Figure 3. A,B, View to acidic ponds developed in the tailings site and samplings campaign; C,D, Acidic ponds developed in the flotation and smelter wastes; E, F, View to sampling for microbiological analysis from acidic ponds. 


\section{BULGULAR}

\section{Maden Atık ve Sediman Jeokimyası}

Balya $\mathrm{Pb}-\mathrm{Zn}$ Maden sahasinda bulunan atıklar, asidik maden drenaji içeren gölet ve dere sedimanları üzerinde gerçekleştirilen kimyasal analiz sonuçları çizelge 1'de verilmiştir. Atıklar üzerinde gerçekleştirilen analiz sonucunda major element siralamas1 $\mathrm{Fe}>\mathrm{Ca}>\mathrm{Al}>\mathrm{K}>\mathrm{Mg}>\mathrm{Mn}>\mathrm{Na}>\mathrm{Ti}>\mathrm{P}$ şeklinde tespit edilmiştir. Major element sıralaması atıkların yüksek oranda $\mathrm{Fe}, \mathrm{Ca}$ ve $\mathrm{Al}$ içerdiğini ortaya koymuştur.

Atıkların metal içeriği oldukça yüksek olup sirasiyla azalan oranda ortalama \% $12.8 \mathrm{Fe}$, $9845 \mathrm{mg} / \mathrm{kg} \mathrm{Pb}, 8975.3 \mathrm{mg} / \mathrm{kg} \mathrm{Zn}, 3300 \mathrm{mg} / \mathrm{kg}$ As, $1501 \mathrm{mg} / \mathrm{kg} \mathrm{Cu}, 255 \mathrm{mg} / \mathrm{kg}$ Co ve $221 \mathrm{mg} / \mathrm{kg}$ $\mathrm{Cd}$ içermektedir. Atıklarda tespit edilen metaller, Balya $\mathrm{Pb}-\mathrm{Zn}$ maden yatağının sülfür mineralojisi ile uyumludur ve ana kaynak olarak sülfürlü mineralleri işaret etmektedir (Çizelge 2). Maden atıklarında tespit edilen yüksek $\mathrm{Pb}(9845 \mathrm{mg} /$ $\mathrm{kg})$ ve $\mathrm{Zn}(8975,3 \mathrm{mg} / \mathrm{kg}$ ) değerleri, ana kaynak olarak galen ve sfaleriti işaret etmektedir. Ayrıca, atıklarda tespit edilen ikincil mineraller $\mathrm{Pb}, \mathrm{Zn}$, $\mathrm{Fe}$ ve As metalleri için önemli birer kaynaktır (Çizelge 3). Özellikle atıklarda tesbit edilen düşük çözünürlüklü anglezit minerali $\mathrm{Pb}$ elementi için kaynak teşkil etmektedir (Çizelge 2). . Pirit ve ikincil Fe oluşumları atıklarda ölçülen yüksek Fe (\%12.81)'in kaynağını oluşturmaktadır. Atıkların ortalama As ve $\mathrm{Cu}$ konsantrasyonu sirasiyla $3300 \mathrm{mg} / \mathrm{kg}$ ve $1501 \mathrm{mg} / \mathrm{kg}$ olarak saptanmıştır. Atıkların içerdiği arsenopirit ve kalkopirit ile Balya cevherleşmesinde daha az oranda bulunduğu bilinen tetrahedrit, realgar ve orpiment mineralleri söz konusu metallerin ana kaynakları olmalıdır. Atıkların $\mathrm{Cd}$ ve Co içerikleri diğer elementlere oranla daha düşüktür. Atıkların içinde bolca bulunan pirit, ve özellikle sfaleritin $\mathrm{Cd}$ ve Co ile $\mathrm{Sn}$, Se ve Ni gibi diğer iz elementlerlere kaynak teşkil ettiği daha önceki çalışmalarda belirtilmiştir (Kovenko, 1940). Yine aynı çalışmada, galenin \% $0.11 \mathrm{Sn}, \% 0.01 \mathrm{Bi}, \% 0.54 \mathrm{Cu}, \% 0.03 \mathrm{Fe}, 0.004$ Ni ve \% 0.01 oranında As içerdiği tespit edilmiştir (Kovenko, 1940).

Asidik maden drenaji içeren göletlerden toplanan Fe oksi-hidroksitlerce zengin çökellerin metal içeriği, atıkların metal içeriği ile benzerlik sergilemektedir (Çizelge 1). Bu veriler, atıklardan salınan $\mathrm{Pb}, \mathrm{Zn}, \mathrm{Cd}, \mathrm{Co}$, As ve Cu'ın Feoksitlere adsorb olduğunu göstermektedir. AS1 asidik göletinden alınan Fe'ce zengin çökeller üzerinde yapılan XRD çalışmaları sonucunda elde edilen veriler Çizelge 3'de sunulmuştur. Çizelge 3'den görüldüğü gibi asidik göletler içerisinde As, $\mathrm{Zn}, \mathrm{Pb}$ ve Fe'li birçok değişik mineral bulunmaktadır. Fe'ce zengin çökellerin tüm metal içerikleri yüksek olmasına karşın özellikle As ve $\mathrm{Cu}$ değerleri dikkat çekicidir; ve söz konusu elementlerin Fe oksitlere olan yüksek bağlanma isteği ile uyumludur (Balc1, 2010). Asidik göletlerde tesbit edilen plumbojarosit, jarosit ve götit gibi Fe oksi-hidroksitlerin geniş yüzey alanları nedeniyle metalleri kolaylıkla adsorb ettikleri daha önceki çalışmalarda da tesbit edilmiştir (Balcı, 2010; Randall vd.,2001). Tüm bu veriler, atıkların çevresinde oluşan Fe oksihidroksitlerin atıklardan salınan metalleri adsorb ederek taşınmalarını denetlediğini göstermektedir. Atık sahasından geçen Maden deresinden toplanan sediman örneklerinde gerçekleştirilen kimyasal analiz sonuçlarına göre $\mathrm{Fe}_{2} \mathrm{O}_{3}$ oran1 \%11,9 ortalama değeri ile maden atık kimyasına oldukca yakın değerler vermiştir. Atık sahasına olan yakınlıkla bu değerler yükselmiş ve en yüksek değer \% 18,2 olarak MDS2 sediman örneğinde saptanmıştır. Maden atıkları ile uyumlu olarak, dere sedimanlarında da yüksek metal değerleri elde edilmiştir (Çizelge 1). 
Çizelge 1. Balya $\mathrm{Pb}-\mathrm{Zn}$ Maden atık sahasından alınan maden atığı, asidik su sedimanı ve Maden Deresi sedimanlarının kimyasal analiz sonuçları.

Table 1. Chemical data for mine wastes and sediment from acidic ponds and Maden Creek.

\begin{tabular}{|c|c|c|c|c|c|c|c|c|c|c|c|c|c|c|c|c|}
\hline & $\begin{array}{c}\mathrm{Al}_{2} \mathrm{O}_{3} \\
\%\end{array}$ & $\begin{array}{c}\mathrm{Fe}_{2} \mathrm{O}_{3} \\
\%\end{array}$ & $\begin{array}{c}\text { MgO } \\
\%\end{array}$ & $\begin{array}{c}\mathrm{CaO} \\
\%\end{array}$ & $\begin{array}{c}\mathrm{Na}_{2} \mathrm{O} \\
\%\end{array}$ & $\begin{array}{c}\mathrm{K}_{2} \mathrm{O} \\
\%\end{array}$ & $\begin{array}{c}\mathrm{TiO}_{2} \\
\%\end{array}$ & $\begin{array}{c}\mathbf{P}_{2} \mathbf{O}_{5} \\
\%\end{array}$ & $\begin{array}{c}\text { MnO } \\
\%\end{array}$ & $\begin{array}{c}\mathrm{Pb} \\
\mathrm{mg} / \mathrm{kg}\end{array}$ & $\begin{array}{c}\mathrm{Zn} \\
\mathrm{mg} / \mathrm{kg}\end{array}$ & $\begin{array}{c}\mathrm{Cu} \\
\mathrm{mg} / \mathrm{kg}\end{array}$ & $\begin{array}{c}\text { As } \\
\mathrm{mg} / \mathrm{kg}\end{array}$ & $\begin{array}{c}\mathrm{Co} \\
\mathrm{mg} / \mathrm{kg}\end{array}$ & $\begin{array}{c}\mathrm{Cd} \\
\mathrm{mg} / \mathrm{kg}\end{array}$ & $\begin{array}{c}\text { Corg } \\
\%\end{array}$ \\
\hline Maden Atığ & & & & & & & & & & & & & & & & \\
\hline $\begin{array}{l}\text { ortalama } \\
\qquad(n=5)\end{array}$ & 6.75 & 12.81 & 1.23 & 11.23 & 0.52 & 3.75 & 0.19 & 0.07 & 0.76 & 9845 & 8975.3 & 1501 & 3300 & 255 & 221 & 0.1 \\
\hline $\begin{array}{c}\text { Asidik Su } \\
\text { Sedimanı } \\
\text { ortalama } \\
(n=3)\end{array}$ & 12.6 & 30.23 & n.d & n.d & n.d & n.d & n.d & n.d & n.d & 7550 & 6232.8 & 2560.4 & 5230 & 56.4 & 45.8 & 2.4 \\
\hline $\begin{array}{c}\text { Dere Sedimanı } \\
\text { ortalama } \\
(n=5)\end{array}$ & 8.32 & 11.9 & 0.85 & 5.36 & 0.65 & 1.98 & 0.28 & 0.14 & 0.65 & 4678.2 & 4332.1 & 875 & 1876 & 45.7 & 35.3 & 12 \\
\hline
\end{tabular}

Çizelge 2. Balya $\mathrm{Pb}-\mathrm{Zn}$ maden atıklarında XRD ile tespit edilen mineraller

Table 2. Mineralogical composition of Balya $\mathrm{Pb}-\mathrm{Zn}$ Mine tailings determined by XRD

\begin{tabular}{|c|c|}
\hline Mineral & İdeal Bileşimi \\
\hline Sfalerit & $(\mathrm{Fe}, \mathrm{Zn}) \mathrm{S}$ \\
\hline Pirit & $\mathrm{FeS}_{2}$ \\
\hline Galen & $\mathrm{PbS}$ \\
\hline Kalkopirit & $\mathrm{CuFeS}_{2}$ \\
\hline Arsenopirit & AsFeS \\
\hline Kuvars & $\mathrm{SiO}_{2}$ \\
\hline Kükürt & $\mathrm{S}$ \\
\hline $\begin{array}{l}\text { Anglezit } \\
\text { Jips }\end{array}$ & $\begin{array}{l}\mathrm{PbSO}_{4} \\
\mathrm{CaSO}_{4}\end{array}$ \\
\hline Kalsit & $\mathrm{CaCO}_{3}$ \\
\hline K-Felspat & $\mathrm{KalSi}_{3} \mathrm{O}_{8}$ \\
\hline Dolomit & $\mathrm{Ca}, \mathrm{Mg}\left(\mathrm{CO}_{3}\right)_{2}$ \\
\hline
\end{tabular}

Çizelge 3. ASS1 asidik sediman örneğinde XRD ile tespit edilen Fe ve diğer metallerin ikincil türleri

Table 3. Fe minerals and secondary minerals of ASS1 acidic sediman sample determined by XRD

\begin{tabular}{ll}
\hline Mineral isimleri & İçerikleri \\
\hline Scorodit & $\mathrm{Fe}$, As minerali \\
Paulmooreit & $\mathrm{Pb}$, As minerali \\
Anglezit & $\mathrm{Pb}$ minerali \\
Kintoreit & $\mathrm{Fe}, \mathrm{Pb}$ minerali \\
Adamit & $\mathrm{Zn}$, As minerali \\
Koritnigit & $\mathrm{Zn}$, As minerali \\
Plumbojarosit & $\mathrm{Fe}, \mathrm{Pb}$ minerali \\
Götit & $\mathrm{Fe}$ minerali \\
Jarosit & $\mathrm{Fe}$ minerali \\
\hline
\end{tabular}




\section{Asidik ve Yüzey Su Jeokimyası}

Balya $\mathrm{Pb}-\mathrm{Zn}$ atık alanlarında oluşan asidik maden suları ile Maden deresinden toplanan yüzey su örneklerinin analiz sonuçları Çizelge 4 ve 5 'de sunulmuştur . Maden atık sahası civarında yağışlar nedeniyle oluşan küçük ve büyük boyutlu sığ asidik sular oldukça düşük $\mathrm{pH}$ değerlerine sahiptir. Asidik suların ortalama pH değeri 2.69 olarak hesaplanmıştır (Çizelge 4). Oldukça düşük pH’lı ve yüksek Eh'lı bu asidik sular etraftaki kayaçları çözerek birçok metali bünyesine katmaktadır . Asidik sularda ölçülen yükssek elektriksel iletkenlik değerleri suların yüksek çözünmüş iyon içeriği ile uyumludur (Çizelge 4). Asidik suların sülfat içeriği $4500 \mathrm{mg} / \mathrm{L}$ ile $9750 \mathrm{mg} / \mathrm{L}$ arasında değişmektedir. Bununla uyumlu olarak, $\mathrm{Mg}$, ve $\mathrm{K}$ değerleri de yüzey sularına oranla daha yüksektir (Çizelge 2). Maden atıklarının yakınından geçen Maden Deresi üzerinden alınan yüzey su örneklerinin (YS1-YS5) iyon içerikleri asidik su örneklerine oranla oldukça düşüktür. Atıklara olan uzaklık ile bu değerler daha da azalmaktadır. Atıklardan oldukça uzakta, Kocaçaya yakın kontrol amaçlı alınan örneğin (YS6 ), atıklara yakın kesimden alınan diğer su örneklerine oranla tüm iyon içeriği önemsiz değerler sergilemiştir
(Çizelge 4 ve Şekil 6). Atıklardan uzakta alınan YS6 örneğinin sülfat değeri de diğer örneklere oranla oldukça düşüktür. Bu veriler atıklardan kaynaklanan yüksek iyon içerikli asidik suların derelere taşındığını; ve ana kaynağın atıklar olduğunu göstermektedir. Kuru ve yaş döneme ait asidik ve yüzey su örneklerinin metal içerikleri Çizelge 5 'de sunulmuştur. Her iki dönemde de asidik sular, yüksek metal ve Al içerikleri ile yüzey sularından kolaylıkla ayrılmaktadır. Zn konsantrasyonu asidik sularda en düşük 68.9 mg/L en yüksek 546.5 mg/L olarak ölçülmüş̧ür. $\mathrm{Fe}_{\text {tot }}$ konsantrasyonu $\mathrm{Zn}$ ile uyumlu olarak asidik sularda yüksek ölçülmüştür. Asidik sularda ölçülen $\mathrm{Fe}_{\text {tot }}$ 'in \% 90'nını $\mathrm{Fe}$ (III) iyonu oluşturmaktadır ( Çizelge 5). $\mathrm{Pb}$ ve $\mathrm{Cu}$, Zn'dan sonra ölçülen en yükssek metallerdir. Yüzey su örneklerine oranla, asidik sular yüksek oranda $\mathrm{Cu}$, As ve $\mathrm{Pb}$ içermektedir. Özellikle asidik sularda $3.12 \mathrm{mg} / \mathrm{L}$ ye ulaşan $\mathrm{Pb}$ konsantrasyonu pekçok su standartlarına göre oldukça yüksektir (WHO, EPA). Cu konsantrasyonu en yüksek $26.67 \mathrm{mg} / \mathrm{L}$ olarak AS2 örneğinde, en düşük $9.8 \mathrm{mg} / \mathrm{L}$ olarak AS5 asidik su örneğinde ölçülmüştür.. Analizler sonucunda asidik suların As içeriğide WHO ve EPA standartlarına oranla yüksek tespit edilmiştir (Çizelge 5).

Çizelge 4. Balya Pb-Zn atık sahasından toplanan asidik sular (AS) ve yüzey sularının (YS) jeokimyası ile toplam S ve Fe oksitleyen mikroorganizma miktarı

Table 4. Aqeous geochemistry and Total S and Fe oxidizing microorganims of acidic (AS) and surface water (YS) collected from Balya Pb-Zn mine tailings site.

\begin{tabular}{|c|c|c|c|c|c|c|c|c|c|c|c|c|c|}
\hline Asidik Sular & pH & $\begin{array}{c}\text { Eh } \\
(\mathrm{mV})\end{array}$ & $\begin{array}{c}\text { EC } \\
(\mu \mathrm{S} / \mathrm{cm})\end{array}$ & $\begin{array}{c}\mathrm{T} \\
\mathbf{0 C}\end{array}$ & $\begin{array}{c}\mathrm{SO}_{4} \\
(\mathrm{mg} / \mathrm{L})\end{array}$ & $\begin{array}{c}\mathrm{Mg}^{2+} \\
(\mathrm{mg} / \mathrm{L})\end{array}$ & $\begin{array}{c}\mathrm{Na}^{+} \\
(\mathrm{mg} / \mathrm{L})\end{array}$ & $\begin{array}{c}\mathrm{Ca}^{2+} \\
(\mathrm{mg} / \mathrm{L})\end{array}$ & $\begin{array}{c}\mathrm{K}^{+} \\
(\mathrm{mg} / \mathrm{L})\end{array}$ & $\begin{array}{c}\mathrm{CI}^{-} \\
(\mathrm{mg} / \mathrm{L})\end{array}$ & $\begin{array}{c}\mathrm{NO}_{3} \\
(\mathrm{mg} / \mathrm{L})\end{array}$ & $\begin{array}{l}\text { MPN-S } \\
\text { (cell/ml) }\end{array}$ & $\begin{array}{l}\text { MPN-Fe } \\
\text { (cell } / \mathrm{ml})\end{array}$ \\
\hline $\mathrm{AS} 1$ & 2.83 & 450 & 19000 & 22 & 8690 & 95.1 & 45.2 & 456 & 5.2 & 35.2 & 6 & $4.4 \times 10^{8}$ & $2.8 \times 10^{8}$ \\
\hline AS2 & 2.60 & 550 & 15200 & 26 & 9750 & 89.2 & 15.2 & 231 & n.d & 56.1 & 5.1 & $3.7 \times 109$ & $2.1 \times 107$ \\
\hline AS3 & 2.75 & 323 & 12500 & 25 & 9636 & 56 & 16.1 & 552 & 3.4 & 35.1 & 13.2 & $2.7 \times 10^{7}$ & $1.7 \times 10^{8}$ \\
\hline AS4 & 2.80 & 230 & 13200 & 25 & 7686 & 75.2 & 23.1 & 123 & 10.1 & 30 & 11.2 & $2.3 \times 10^{6}$ & $1.5 \times 10^{6}$ \\
\hline AS5 & 2.50 & 320 & 10890 & 26 & 4500 & 78.1 & 22.3 & 168 & 12.2 & 45 & 10 & $5.1 \times 10^{7}$ & $1.1 \times 10^{7}$ \\
\hline \multicolumn{14}{|l|}{ Yüzey Suları } \\
\hline YS1 & 3.83 & 230 & 230 & 24 & 1560 & 41.2 & 12.3 & 596 & 9.5 & 11.1 & 125 & $1.7 \times 10^{8}$ & $1.7 \times 10^{4}$ \\
\hline YS2 & 3.6 & 235 & 320 & 24 & 1035 & 39.2 & 13.5 & 652 & 9.8 & 15.6 & 145 & $1.0 \times 106$ & $2.7 \times 10^{3}$ \\
\hline YS3 & 3.75 & 94 & 450 & 24 & 1356 & 52.8 & 9.5 & 752 & n.d & 12.3 & 56 & $1.7 \times 10^{7}$ & $1.7 \times 10^{3}$ \\
\hline YS4 & 4.5 & 80 & 321 & 22 & 900 & 41.3 & 7.1 & 589 & 7.1 & 15.2 & 126 & $3 \times 10^{6}$ & $1.7 \times 10^{2}$ \\
\hline YS5 & 5.5 & n.d & 458 & 24 & 750 & 63 & 8.2 & 663.1 & n.d & 16.3 & 132 & $1.7 \times 10^{3}$ & n.d \\
\hline
\end{tabular}




\section{Kültür Temelli Mikrobiyolojik Çalışmalar}

Asidik maden suları içerisinde ototrofik asidofilik sülfür oksitleyen bakteri (aSOB) ve Fe(II) oksitleyen bakteri (aFeOB) miktarları Çizelge 4'de verilmiştir. aSOB için en yüksek değer $4.4 \times 10^{8}$ cell $/ \mathrm{ml}$, aFeOB için aynı değer $2.8 \times 10^{8}$ cell/ml olarak en geniş ve uzun ömürlü asidik gölette ölçülmüştür (AS1) (Şekil 3a). Asidik sular içerisinde asidofilik $\mathrm{Fe}(\mathrm{III})_{\mathrm{aq}}$ indirgeyen bakteri (aFeIB) $10^{3}$ cell $/ \mathrm{ml}$ olarak yalnızca AS1 ve AS2 sularında tespit edilmiş ve diğer mikroorganizmalara oranla oldukça düşük değerlere ulaşmıştır. Atıkların Maden deresine ulaştığı kesimlerden alınan yüzey sularında en yüksek aSOB $1.7 \times 10^{7}$ cell $/ \mathrm{ml}$ olarak, aFeOB ise $1.7 \times 10^{4}$ cell $/ \mathrm{ml}$ olarak YS1 su örneğinde tespit edilmiştir. Asidik sular, yüzey su örneklerine oranla daha yüksek miktarda bakteri içermektedir. Özellikle aFeOB miktari $10^{4}$ oranında daha azdır. Hem asidik hem de yüzey sularında aSOB miktari oldukça yüksektir.

\section{S rDNA Metodu ile Tür Belirleme Çalışmaları}

Asidik sediman ile Maden Deresinden toplanan sediman örnekleri üzerinde biyomoleküler tekniklerle tespit edilen ve yalnızca $S$ ve Fe döngüsünde etkili mikroorganizma türleri Çizelge 6'da verilmiştir. Analiz edilen tüm sediman örneklerinde $\gamma$-Proteobacteria ve $\beta$-Proteobacteria grubu ağırlıklı, daha az oranda ise Firmicutes ve $\delta$-Proteobacteria grubuna ait mikroorganizmalar tespit edilmiştir.

Atıkların içerisinde ve yakınlarında gelişen göletlerden toplanan ASS1, ASS2 ve ASS3 sediman örneklerinde, sülfür ve Fe oksidasyonunda etkili türler tespit edilmiştir. Sözkonusu örneklerde, sülfür oksidasyonunda etkili Acidithiobacillus spp . cinsine ait 12 faklı tür saptanmıştır (Çizelge 6). Bunlar arasında en önemlileri, AMD oluşumuna neden olduğu bilinen ve bu tür sahalarda yaygın olarak bulunan Acidithiobacillus ferrooxidans türüne sırasıyla \% 95, 96, 93 oranında benzerlik gösteren Acidithiobacillus ferrooxidans strain

Çizelge 5. Balya $\mathrm{Pb}-\mathrm{Zn}$ atık sahasından toplanan asidik su (AS) ve yüzey su (YS) örneklerinin metal içerikleri

Table 5. Metal contents of acidic (AS) and surface water (YS) from Balya Pb-Zn tailings site.

\begin{tabular}{|c|c|c|c|c|c|c|c|c|c|c|c|c|c|c|c|}
\hline $\begin{array}{c}\text { Su } \\
\text { Örnekleri }\end{array}$ & $\begin{array}{c}\mathrm{Al} \\
(\mu \mathrm{g} / \mathrm{L})\end{array}$ & $\begin{array}{c}\text { As } \\
(\mu \mathrm{g} / \mathrm{L})\end{array}$ & $\begin{array}{c}\text { Cd } \\
(\mu \mathrm{g} / \mathrm{L})\end{array}$ & $\begin{array}{c}\text { Co } \\
(\mu \mathrm{g} / \mathrm{L})\end{array}$ & $\begin{array}{c}\mathrm{Cr} \\
(\mu \mathrm{g} / \mathrm{L})\end{array}$ & $\begin{array}{c}\mathrm{Cu} \\
(\mu \mathrm{g} / \mathrm{L})\end{array}$ & $\begin{array}{c}\mathrm{Fe} \\
(\mu \mathrm{g} / \mathrm{L})\end{array}$ & $\begin{array}{l}\mathrm{Fe}(\mathrm{II}) \\
(\mu \mathrm{g} / \mathrm{L})\end{array}$ & $\begin{array}{c}\mathrm{Fe}(\mathrm{III}) \\
(\mu \mathrm{g} / \mathrm{L})\end{array}$ & $\begin{array}{c}\text { Mn } \\
(\mathrm{mg} / \mathrm{L})\end{array}$ & $\begin{array}{c}\mathrm{Ni} \\
(\mu \mathrm{g} / \mathrm{L})\end{array}$ & $\begin{array}{c}\mathrm{Pb} \\
(\mu \mathrm{g} / \mathrm{L})\end{array}$ & $\begin{array}{c}\mathrm{Zn} \\
(\mu \mathrm{g} / \mathrm{L})\end{array}$ & $\begin{array}{c}\mathrm{Si} \\
(\mu \mathrm{g} / \mathrm{L})\end{array}$ & $\begin{array}{c}\mathrm{S} \\
(\mathrm{mg} / \mathrm{L})\end{array}$ \\
\hline AS1 & 78520 & 575 & 2300 & 192 & 30.2 & 13352 & 742200 & 90200 & 652000 & 150 & 54.3 & 2189 & 546467 & 22178 & 1585 \\
\hline AS2 & 76612 & 1506 & 1143 & 274 & 103.2 & 26670 & 669675 & 94425 & 575250 & 1076 & 179.3 & 3129 & 215489 & 15929 & 4250 \\
\hline AS3 & 33520 & 5986 & 2716 & 187 & 66 & 23350 & 933425 & 71425 & 862000 & 133.7 & 100 & 1914 & 299410 & 17140 & 2909 \\
\hline AS4 & 19963 & 3264 & 978 & 77.7 & 62 & 12365 & 236200 & 5200 & 231000 & 89 & 78.5 & 1230 & 76744 & 9652 & 2562 \\
\hline AS5 & 15230 & 1230 & 589 & 59.1 & 45.2 & 9870 & 523000 & 71000 & 452000 & 96 & 89 & 956.5 & 68900 & 6530 & 1500 \\
\hline YS1 & 152 & 440 & 15.4 & 12.72 & n.d & 53.6 & 52700 & n.d. & n.d. & 62.3 & 34.44 & 78 & 10980 & 8964 & 810 \\
\hline YS2 & 49 & 176 & 23.6 & 15.3 & n.d & 36.6 & 3896 & n.d. & n.d. & 59 & 32.5 & 25 & 13714 & 6724 & 545 \\
\hline YS4 & 122 & 5.8 & n.d & 0.3 & n.d & 7.6 & 161.7 & n.d. & n.d. & 10.2 & 15.2 & 33 & 3910 & 5960 & 475 \\
\hline YS5 & 21 & 18.2 & n.d & 58.8 & n.d & 9.9 & 786 & n.d. & n.d. & 70.1 & 14.4 & 62.1 & 72300 & 3562 & 250 \\
\hline YS6* & 12 & 2.52 & $<0.3$ & 1.2 & n.d & 3.3 & 56.1 & n.d. & n.d. & 7.2 & 0.1 & 7.08 & 12.24 & n.d & 17.8 \\
\hline
\end{tabular}


S1, Acidithiobacillus ferrooxidans strain SY3 ve Acidithiobacillus ferrooxidans strain N16 türleridir. ASS1, ASS2 ve ASS3 örneklerinde tespit edilen diğer önemli asidofilik sülfür oksitleyen tür ise Acidithiobacillus thiooxidans strain ATCC 19377 ve Sulfobacillus cinsine bağlı türlerdir. Asidik sediman örneklerinde Fe oksidasyonunda ve indirgenmesinde etkili türler de tespit edilmiştir. Fe(II) oksitleyici olarak Acidithiobacillus spp.cinsine bağ $\mathrm{l}_{1}$ A. ferrooxidans türü ile Leptothrix spp. cinsine bağl1 Leptothrix $s p$. ve Leptothrix sp.S1.1 türleri tespit edilmiştir. $\mathrm{Fe}(\mathrm{III})$ 'ün indirgenmesinden sorumlu üç farklı cinse bağlı toplam 3 farklı bakteri türü tespit edilmiştir. Bunlar Ferribacterium limneticum, Rhodoferax ferrireducens T118 ve Geobacter $s p$. türleridir. Maden deresi üzerinden alınan sediman örneklerinin tür içerikleri asidik sediman örneklerine oldukça benzerdir. Özellikle, atıklara yakın kesimden alınan sediman (MDS1ve MDS2) örneklerinde bu benzerlik daha belirgindir. MDS1, MDS2 ve MDS3 örneklerinde $\gamma$-Proteobacteria ve $\beta$-Proteobacteria filogenetik grubuna yakin benzerlik gösteren sülfür oksitleyici türler tespit edilmiştir. Acidithiobacillus cinsine ait sülfür oksitleyicilerin yanı sıra, Thiobacillus cinsine ait Thiobacillus thiophilus, Thiobacillus denitrificans ATCC 25259 sülfür oksitleyici türler sadece bu sediman örneklerinde tespit edilmiştir. Acidovorax sp. G8B1, Ferrovum myxofaciens strain $P 3 G$ ve Acidithiobacillus ferrooxidans strain $S 1$ dere sedimanlarında tespit edilen $\mathrm{Fe}(\mathrm{II})$ oksitleyici bakterilerdir. Geobacter MDS1 ve MDS2 örneğinde, Ferribacterium limneticum, Rhodoferax ferrireducens T118 ise MDS3 örneğinde tespit edilen Fe(III) indirgeyici mikroorganizmalardır. Arsenik döngüsünde etkili olduğubilinen Comamonadaceae bacterium PIV81 bakterisi MDS1, MDS2 ve MDS3 örneklerinde saptanmıştır. Maden atıklarından uzakta alınan MDS4 sediman örneğinde $\mathrm{Fe}$ ve $\mathrm{S}$ oksitleyici mikroorganizmalar oldukça azdır. S oksitleyici olarak yalnızca Thiobacillus denitrificans ATCC 25259 ile Acidithiobacillus thiooxidans strain ABRM 2011 türleri saptanmıştır. Fe indirgeyici olarak ise Ferribacterium limneticum ile Geobacter cinsine bağlı tek tür belirlenmiştir. Bunun aksine, MDS4 örneğinde yoğun olarak $\beta$-Proteobacteria grubuna bağlı nitrojen döngüsünde etkili bakteriler tespit edilmiştir. MDS3 örneğinde olduğu gibi selenatın indirgenmesinde etkili Dechloromonas $s p . H Z$ türü bu örnekte de saptanmıştır. 
Çizelge 6. $16 \mathrm{~S}$ rDNA Dizi Analizi ile atık sahasında tespit edilen mikroorganizma türleri ve metabolik fonksiyonları.

Table 6. Microorganims determined by $16 S$ rDNA gene sequencing in the mine tailings site and their metabolic functions.

\begin{tabular}{|c|c|c|c|c|}
\hline Örnek & Organizma Adı & $\begin{array}{c}\text { Benzerlik } \\
\%\end{array}$ & Filogenetik Grup & Metabolik Fonksiyon \\
\hline & Acidithiobacillus ferrooxidans strain $\mathrm{S} 1$ & 95 & $\gamma$-Proteobacteria & Fe ve $\mathrm{S}$ oksidasyonu \\
\hline & Acidithiobacillus ferrooxidans strain SY3 & 96 & $\gamma$-Proteobacteria & Fe ve $\mathrm{S}$ oksidasyonu \\
\hline & Acidithiobacillus ferrooxidans strain N16 & 93 & $\gamma$-Proteobacteria & Fe ve S oksidasyonu \\
\hline & Acidithiobacillus sp Peru 6 & 92 & $\gamma$-Proteobacteria & Fe ve S oksidasyonu \\
\hline & Acidithiobacillus sp OP 14 & 92 & $\gamma$-Proteobacteria & Fe ve S oksidasyonu \\
\hline & Acidithiobacillus albertensis strain DSM 14366 & 93 & $\gamma$-Proteobacteria & \\
\hline & Acidithiobacillus thiooxidans strain ATCC 19377 & 95 & $\gamma$-Proteobacteria & Fe ve S oksidasyonu \\
\hline & Acidithiobacillus sp. $l s h-01$ & 92 & $\gamma$-Proteobacteria & Fe ve S oksidasyonu \\
\hline & Acidithiobacillus ferrooxidans & 94 & $\gamma$-Proteobacteria & Fe ve S oksidasyonu \\
\hline & Uncultured bacterium clone FZ-7 & 95 & $\gamma$-Proteobacteria & \\
\hline & Uncultured Acidithiobacillus sp. clone XJ79 & 96 & & Fe ve S oksidasyonu \\
\hline & Acidithiobacillus sp. Mc9KA-2-1-4 & 95 & $\gamma$-Proteobacteria & Fe ve $\mathrm{S}$ oksidasyonu \\
\hline ASS1 & Uncultured Acidithiobacillus sp. clone AS3_bact_h10 & 95 & $\gamma$-Proteobacteria & Fe ve S oksidasyonu \\
\hline ASS2 & Uncultured bacterium clone $S X 2-15$ & 96 & $\gamma$-Proteobacteria & \\
\hline \multirow[t]{13}{*}{ ASS3 } & Acidithiobacillus thiooxidans strain ATCC 19377 & 93 & $\gamma$-Proteobacteria & S oksidasyonu \\
\hline & Uncultured bacterium clone Z132 & 93 & & \\
\hline & Uncultured bacterium clone Y1-25 & 91 & & \\
\hline & Uncultured bacterium clone M1-24 & 91 & & \\
\hline & Uncultured Sulfobacillus sp. clone K6-C156 & 92 & Firmicutes & $\mathrm{Fe}$ ve $\mathrm{S}$ oksidasyonu/ $\mathrm{Fe}$ indirgenmesi \\
\hline & Sulfobacillus sp. $4 G$ & 94 & Firmicutes & $\mathrm{Fe}$ ve $\mathrm{S}$ oksidasyonu/ $\mathrm{Fe}$ indirgenmesi \\
\hline & Uncultured bacteria clone F2-49 & 95 & & \\
\hline & $\begin{array}{l}\text { Uncultured bacterium partial } 16 S \text { rRNA gene, clone } \\
\text { OZ-WIN39 }\end{array}$ & 92 & & \\
\hline & Ferribacterium limneticum & 93 & $\beta$-Proteobacteria & $\mathrm{Fe}(\mathrm{III})$ indirgenmesi \\
\hline & Rhodoferax ferrireducens $\mathrm{T} 118$ & 93 & $\beta$-Proteobacteria & Fe(III) indirgenmesi \\
\hline & Geobacter & 95 & $\beta$-Proteobacteria & $\mathrm{Fe}(\mathrm{III})$ indirgenmesi \\
\hline & Leptothrix sp & 93 & $\beta$-Proteobacteria & Mn ve Fe oksidasyonu \\
\hline & Leptothrix sp. S1.1 & 87 & $\beta$-Proteobacteria & Mn ve Fe oksidasyonu \\
\hline
\end{tabular}


Çizelge 6. Atık sahasında tespit edilen mikroorganizma türleri ve metabolik fonksiyonları (Devamı)

Table 6. Microorganims determined in the mine tailings site and their metabolic functions (Continued)

\begin{tabular}{|c|c|c|c|c|}
\hline Örnek & Organizma Adı & $\begin{array}{c}\text { Benzerlik } \\
\%\end{array}$ & Filogenetik Grup & Metabolik Fonksiyon \\
\hline & Acidithiobacillus thiooxidans strain ABRM2011 & 91 & $\gamma$-Proteobacteria & S oksidasyonu \\
\hline & Acidithiobacillus ferrooxidans strain $\mathrm{S} 1$ & 97 & $\gamma$-Proteobacteria & $\mathrm{S}$ ve Fe oksidasyonu \\
\hline & Thiovirga sulfuroxydans & 97 & $\gamma$-Proteobacteria & S oksidasyonu \\
\hline & Thiobacillus thiophilus & 94 & $\beta$-Proteobacteria & S oksidasyonu \\
\hline & Thiobacillus denitrificans ATCC 25259 & 97 & $\beta$-Proteobacteria & Sve Fe oksidasyonu \\
\hline & Thiobacillus denitrificans ATCC 25259 & 97 & $\beta$-Proteobacteria & S ve Fe oksidasyonu \\
\hline & Uncultured Thiobacillus sp. clone ENR10 & 93 & $\beta$-Proteobacteria & S oksidasyonu \\
\hline & Geobacter & 91 & $\delta$-Proteobacteria & Fe indirgenmesi \\
\hline MDS1 & Uncultured Geobacteraceae bacterium & 91 & $\delta$-Proteobacteria & Fe indirgenmesi \\
\hline MDS2 & Ferrovum myxofaciens strain $P 3 G$ & 95 & $\delta$-Proteobacteria & Fe oksidasyonu \\
\hline \multirow[t]{8}{*}{ MDS3 } & Comamonadaceae bacterium PIV81 & 90 & $\beta$-Proteobacteria & Arsenat İndirgenmesi \\
\hline & Chromatiales bacterium & 94 & $\beta$-Proteobacteria & Anaerobik kükürt oksidasyonu \\
\hline & Acidovorax sp. G8B1 & 97 & $\gamma$-Proteobacteria & Fe Oksidasyonu \\
\hline & Uncultured Sulfobacillus sp.clone SN1_2009_10D & 91 & Firmicutes & Fe ve S oksidasyonu/ Fe indirgenmesi \\
\hline & Uncultured Sulfobacillus sp. clone K6-C156 & 91 & Firmicutes & Fe ve S oksidasyonu/ Fe indirgenmesi \\
\hline & Halothiobacillus sp. NP37 & 95 & $\gamma$-Proteobacteria & S Oksidasyonu \\
\hline & Dechloromonas sp. HZ & 93 & $\beta$-Proteobacteria & Selenat indirgenmesi \\
\hline & Acidovorax avenae & 100 & $\beta$-Proteobacteria & $?$ \\
\hline \multirow[t]{4}{*}{ MDS4 } & Acidithiobacillus thiooxidans strain ABRM2011 & 91 & $\gamma$-Proteobacteria & S oksidasyonu \\
\hline & Uncultured Geobacteraceae bacterium & 91 & $\delta$-Proteobacteria & Fe indirgenmesi \\
\hline & Ferribacterium limneticum & 94 & $\beta$-Proteobacteria & Fe indirgenmesi \\
\hline & Thiobacillus denitrificans ATCC 25259 & 97 & $\beta$-Proteobacteria & S oksidasyonu \\
\hline
\end{tabular}

\section{TARTIŞMA}

\section{Balya Pb-Zn Maden Atık Sahasının Mikrobiyal Topluluğu}

Yapılan bu çalışmayla, Balya $\mathrm{Pb} \mathrm{Zn}$ Maden atık sahasının mikrobiyal topluluğu, kültürleme ve moleküler ekoloji teknikleri birlikte kullanılarak, ilk defa ortaya konmuştur. Çalışmayla elde edilen veriler, Balya maden atık sahasının Fe ve $\mathrm{S}$ oksidasyonu ile devamlılı̆̆ını sağlayan mikroorganizmalar tarafindan oldukça zengin olduğunu göstermiştir. $\mathrm{Bu}$ mikrooganizmalar, kendileri için gerekli tüm besiyerleri (fosfat vb. iyonlar) ve diğer gerekli malzemeler $\left(\mathrm{CO}_{2}, \mathrm{O}_{2}, \mathrm{~N}_{2}\right)$ 
ile enerjiyi havadan, metal sülfür minerallerinden ve asidik drenaj suyundan elde etmektedirler. En yoğun bakteri içeren ortamlar atıklar ile atıkların üzerinde gelişen asidik özellikli su birikintileridir. Yapılan moleküler ve mikrobiyolojik çalışma atık sahasında farklı türlerin varlığını ortaya koysa da; yoğun olarak aynı grup vetürdemikroorganizmanın dominant olduğunu göstermiştir. Dominant olan mikroorganizmalar kendileri için gerekli enerjiyi $\mathrm{CO}_{2}{ }^{\prime} \mathrm{i}$ ve metal sülfür minerallerini kullanarak elde eden kemolitotrofik gruba aittir. Organik karbonu kullanan heterotrofik mikroorganizma sayısı özellikle asidik sediman örneklerinde oldukça azdır ve bu sonuç asidik sedimanların düşük organik karbon içeriği ile uyumludur (Çizelge 1). Heterotrofik mikroorganizmalar en fazla organik karbon içeriği yüksek olan MDS4 örneğinde saptanmıştır. Saptanan heterotrofik mikroorganizmaların çoğu azot döngüsünü regüle eden türlerdir. Çizelge' 6 da sunulan türlerin çoğu $\mathrm{Fe}(\mathrm{II})$ ve/veya ortamda bulunan sülfür bileşiklerini oksitleyerek AMD'1 oluşumuna katkıda bulunan prokaryotlardır (Bond vd.,2000; Edwards vd.,2001; Brett ve Banfield, 2003; Druschel vd.,2004). Atıklar ile atıkların ulaştığı Maden Deresinin farklı kesimlerinden alınan örneklerle, ortamdaki mikrobiyal topluluğun yapısında ki değişimler ortaya konmuştur. Mikrobiyal topluluğun yapısı ve türlerin aktivite oranları jeokimyasal faktörlerle sıkı ilişki içindedir. Örneğin, sülfürce zengin, organik karbonca fakir atıklar (AS1-3) Fe ve S oksidasyonununda etkili kemolitotrofik prokaryotların gelişmesine olanak sağlarken; organik karbonca daha zengin ve atıklardan uzaklığı nedeni ile nispeten düşük sülfür bileşikleri içeren dere sedimanları (MDS4) ise $\mathrm{S}$ oksidasyonundan çok azot döngüsünde etkili türlerin geliştiği ortamlardır. Bu veriler, sahada değişen jeokimyasal koşullara uyum sağlayan aktif ve dinamik bir mikrobiyal topluluk olduğunu göstermektedir.

\section{Balya Atık Sahasında Mikrobiyal $S$ ve Fe Döngüsü}

Sahada ayrışmaya maruz kalan sülfürce zengin kayaçların madencilik aktiviteleri ve metalurjik işlemler nedeniyle yüzey alanlarının artması, asit oluşumunu engelleyecek doğal tampon etkisi gösteren kirectaş1/dolomit gibi kayaçların yeterince olmaması nedeniyle Balya'da ki atıklar AMD’ı gelişimine ve çevresel açıdan önemli metallerin ( $\mathrm{Pb}, \mathrm{Zn}, \mathrm{Cu}, \mathrm{As}, \mathrm{Cd}, \mathrm{Co}$ ) ortama salınımına neden olmaktadır. Atıklarda tespit edilen ana sülfür minerallerinden pirit, galen, sfalerit, ve daha az oranda kalkopirit ile arsenopiritin oksidasyonu Balya atık sahasında asidik ve metalce zengin suların oluşumunu ve bileşimini denetlemektedir. Birçok laboratuar çalışmasında bu sülfür minerallerinin oksidasyon reaksiyonları araştırılmıştır (Taylor ve Wheeler, 1984b; Gould vd.,1989, 2003; Nordstrom ve Alpers, 1999; Descostes vd., 2004; Brunner vd.,2008; Balc1 vd., 2007, 2012). AMD'nın başlamasında, oluşmasında ve devam etmesinde ana rolü oynayan metal sülfür minerali pirit olarak kabul edilmektedir ( Descostes vd., 2001; Rimstidt ve Vanguah, 2003; Balcı vd., 2007 ). Pirit aşağıda detayları verilen oksidasyon reaksiyonlarına maruz kalarak, ayrışmaya başlar. Reaksiyon 1'de pirit moleküler $\mathrm{O}_{2}$ ve suyla bir araya gelerek ayrışır ve serbest kalan kükürt oksitlenerek sülfat oluştururken, $\mathrm{Fe}(\mathrm{II})_{\mathrm{aq}}$ ve $\mathrm{H}^{+}$ortama katılır (Rimstidt ve Vanguah, 2003; Brunner vd.,2008).

$\mathrm{FeS}_{2}+7 / 2 \mathrm{O}_{2}+\mathrm{H}_{2} \mathrm{O}$ à $\mathrm{Fe}^{+2}+2 \mathrm{SO}_{4}{ }^{-2}+2 \mathrm{H}^{+}$

$\mathrm{Bu}$ reaksiyonu takiben serbest kalan $\mathrm{Fe}$ (II) reaksiyon 2'de gösterildiği şekilde oksitlenerek $\mathrm{Fe}(\mathrm{III})_{\mathrm{aq}}$ iyonunu meydana getirir. Oluşan Fe(III) aq iyonu ise reaksiyon 3'de gösterildiği üzere piriti hızla oksitleyerek, Reaksiyon 1'e oranla daha da fazla asit üretimine ve $\mathrm{Fe}(\mathrm{II})_{\mathrm{aq}}$ salınımına neden olur. 
$\mathrm{Fe}^{2+}+1 / 4 \mathrm{O}_{2}+\mathrm{H}^{+}$à $\mathrm{Fe}^{+3}+1 / 2 \mathrm{H}_{2} \mathrm{O}$

$\mathrm{FeS}_{2}+14 \mathrm{Fe}^{+3}+8 \mathrm{H}_{2} \mathrm{O}$ à $15 \mathrm{Fe}^{+2}+2 \mathrm{SO}_{4}^{-2}+16 \mathrm{H}^{+}$

Yapılan laboratuar ve arazi temelli çalışmalarla (Schippers vd., 1996; Moses ve Nordstrom, 1987; Rimstidt ve Vanguah, 2003; Balcı vd., 2007) AMD gibi düşük pH koşullarında $(<3)$ piritin biyolojik olarak kimyasal reaksiyonlara oranla çok daha hızlı oksitlendiği ortaya konmuştur Yüzeysel ve düşük pH koşullarında pirit oksidasyonununda etkili mikrobiyal türler çoğunlukla Acidithiobacillus spp. grubuna ait türlerdir. Bu gruptan, $\mathrm{Fe}(\mathrm{II})$ ve $\mathrm{S}$ oksitleme kapasitesine sahip A. ferrooxidans türü birçok değişik çalışmaya konu olmuş ve kimyasal reaksiyona oranla piriti reaksiyon(1) de gösterildiği gibi hızla oksitlediği belirlenmiştir (Nordstrom ve Southam, 1997). Balya atık sahasinda yapılan moleküler biyoloji çalışmaları ile özellikle asidik sediman (ASS1-ASS3) ve asidik su örneklerinde Acidithiobacillus spp. grubuna ait birçok değişik tür tespit edilmiştir (Çizelge 6). Elde edilen bu veriler, Balya atık sahasinda reaksiyon 1'de gösterilen mikrobiyal pirit oksidasyonunun önemli olduğunu göstermektedir. Piritin oksidasyonu sırasında açığa çıkan Fe(II) iyonu Fe oksitleyen bakteriler tarafindan reaksiyon 2 de gösterildiği gibi oksitlenerek Fe(III) oluşumuna neden olmaktadır. Özellikle $\mathrm{pH}<3$ koşullarında kimyasal olarak Fe(II)'nin Fe(III)'e oksitlenme kinetiğinin çok yavaş olması nedeni ile, asidik koşullarda $\quad \mathrm{Fe}(\mathrm{II})$ 'nin $\quad \mathrm{Fe}(\mathrm{III})$ 'e oksitlenmesi mikroorganizmalar tarafindan denetlenmektedir (Balc1 vd.,2007; Druschel vd.,2004). Asidik su örneklerinde $\mathrm{Fe}(\mathrm{II})_{\text {aq }}$ 'ye oranla ölçülen yüksek Fe (III) aq konsantrasyonu ve Balya atık sahasında $\mathrm{Fe}(\mathrm{II})_{\text {aq }}$ 'yi oksitleyen türlerin varlığı sahada aktif mikrobiyal Fe oksidasyonunu göstermektedir. Balya Atık sahasinda Fe(II) oksitleyen mikroorganizmaların varlığı, $\mathrm{Fe}(\mathrm{III})_{\mathrm{aq}}$ iyonunun sürekli ortama salındığını, ve dolayısıyla reaksiyon 3'ün de piritin oksidasyonunda önemli bir reaksiyon mekanizması olduğunu önermektedir. Elde edilen bu sonuçlar daha önceki çalışmalarla da uyumludur ve Balya atık sahasında tespit edilen Acidithiobacillus spp grubununa ait türlerin piritin oksidasyonunu kontrol eden dominant türler olduğunu göstermektedir.

Mikrobiyal Fe(II) oksidasyonu (reaksiyon 2) ile ortama salınan $\mathrm{Fe}(\mathrm{III})$ iyonu $\mathrm{O}_{2}$ 'e oranla kalkopirit, sfalerit, ve galen için daha etkili oksitleyicidir (Rimstidt vd., 1994; Plumlee, 1999). Atık sahasında tespit edilen kalkopirit, sfalerit ve galen $\mathrm{Fe}$ (III) iyonu tarafindan oksitlenerek asit üretimi ile ortama önemli oranda $\mathrm{Cu}, \mathrm{Zn}$, ve $\mathrm{Pb}$ ve daha az oranda $\mathrm{As}, \mathrm{Co}, \mathrm{Cd}$ elementlerinin salınımına neden olmaktadır. Asidik sularda ölçülen yüksek $\mathrm{Zn}, \mathrm{Pb}, \mathrm{Cu}$, ile daha düşük değerde ölçülen As, Co, Cd bunu doğrulamaktadır (Çizelge 5). As'in birincil kaynağı arsenopirit olmasına karşın söz konusu bu sülfür mineralleri de ortama As salınımına neden olmaktadır. Sülfürce zengin kayaçlar içerisinde ki sfalerit $\mathrm{Cd}$ ve Co'ın ana kaynağıdır.

$\mathrm{CuFeS}_{2}+16 \mathrm{Fe}^{3+}+8 \mathrm{H}_{2} \mathrm{O}$ à $\mathrm{Cu}^{+2}+17 \mathrm{Fe}^{+2}+2 \mathrm{SO}_{4}^{-2}+$ $16 \mathrm{H}^{+}$

$\mathrm{ZnS}+8 \mathrm{Fe}^{+3}+4 \mathrm{H}_{2} \mathrm{O}$ à $\mathrm{Zn}^{+2}+8 \mathrm{Fe}^{+2}+\mathrm{SO}_{4}^{-2}+8 \mathrm{H}^{+}$
$\mathrm{PbS}+8 \mathrm{Fe}^{+3}+4 \mathrm{H}_{2} \mathrm{O}$ à $\mathrm{Pb}^{+2}+8 \mathrm{Fe}^{+2}+\mathrm{SO}_{4}^{-2}+8 \mathrm{H}^{+}$

$\mathrm{Fe}(\mathrm{III})$ iyonunun yanı s1ra sahada tespit edilen Acidithiobacillus spp grubuna ait türler de galen, sfalerit ve kalkopirit ile arsenopiriti oksitleme kapasitesine sahiptir ve yapılan arazi ve laboratuar çalışmalarında Acidithiobacillus spp grubuna ait türlerin bu sülfür minerallerini oksitlemede oldukça başarılı olduğu ortaya konmuştur (Schippers vd., 1996; Schippers vd., 2000; Gleisner vd., 2006; Balc1 vd., 2012). Balya at1k sahasında tespit edilen Acidithiobacillus thioxidans ve Acidithiobacillus ferrooxidans türleri birçok çalışmaya konu olmuştur (Suzuki 
vd., 1994; Silva, 2004; Schippers vd.,2004, 2005; Brunner vd., 2008; Balcı vd.,2012). Söz konusu bu türler moleküler $\mathrm{O}_{2}$ 'i kullanarak reaksiyon 7 ve 8 'de gösterildiği gibi sırasıyla galen ve sfaleriti oksitleyebilmektedir (Sand vd., 2001). Reaksiyon 7 ve 8 oksidasyon sırasında elektron alış verişi sonucu meydana gelen kütle dengesini ifade etmekte, oluşan ara sülfür türlerini (örn., $\mathrm{S}^{\circ}, \mathrm{S}_{2} \mathrm{O}_{3}$ ) göstermemektedir.

$\mathrm{PbS}+2 \mathrm{O}_{2}$ à $\mathrm{Zn}^{+2}+\mathrm{SO}_{4}^{-2}$
$\mathrm{ZnS}+2 \mathrm{O}_{2}$ à $\mathrm{Zn}^{+2}+\mathrm{SO}_{4}^{-2}$

$\mathrm{Bu}$ oksidasyon işlemlerinde mikroorganizmanın asıl görevi galen ve sfaleritin yüzeyinde oluşan ve oksidan ile mineral arasında bariyer görevi gören inert kükürtü reaksiyon 9' da verilen şekilde oksitlemektir (Balc1 vd.,2012; Fowler ve Crundwell, 1998; Sasaki vd., 1995).

$\mathrm{S}^{0}+3 / 2 \mathrm{O}_{2}+\mathrm{H}_{2} \mathrm{O} \rightarrow 2 \mathrm{H}^{+}+\mathrm{SO}_{4}$

Kimyasal olarak oksitlenmesi oldukça yavaş olan kükürt mikroorganizma tarafından kolaylıkla oksitlenerek, ortama daha fazla sülfat ve metal $(\mathrm{Pb}, \mathrm{Zn})$ salınımına neden olmaktadır (reaksiyon 9). Arazi çalışmaları sırasında atık yüzeylerinde ve Maden Deresi üzerinde tesbit edilen kükürt oluşumları ile yine MDS1-MDS3 sediman örnekleri üzerinde yalnızca indirgenmiş sülfür türlerini oksitleme kapasitesine sahip türlerin (örn.,Thiovirga sulfuroxydans) tespiti sahada metal sülfür minerallerinin oksidasyonu sonucunda ortaya salınan indigenmiş sülfür türlerinin mikrobiyal olarak oksitlendiğini göstermektedir.

Reaksiyon (7), (8) ve (9) sonucunda pirit oksidasyonuna oranla önemsiz asit salınımı meydana gelmekte, ortama yalnızca metal salınmaktadır. Bu nedenle, Balya atık sahasında pirit oksidasyonu (reaksiyon (1), (3) asit oluşumunun asıl kaynağı olarak görülmektedir.

\section{Balya Atık Sahasında Fe Döngüsü ve Metallerin Dağılımına Etkisi}

Fe-oksitler düşük $\mathrm{pH}$ ve okside ortamlarda yaygındırlar. Pirit ve Fe içeren sülfür minerallerinin oksidasyonu sonucu ortama salınan Fe(II)'i reaksiyon (2)'de gösterildiği şekilde oksitlenerek $\mathrm{Fe}(\mathrm{III})$ iyonunu oluşturmaktadır. Asit koşullarda $(\mathrm{pH}<3)$ Fe oksi-hidroksitlerin oluşumu reaksiyon (2) ile sinırlidir (Moses ve Nordstrom, 1987; Schippers vd., 2000). Asidik sediman örneklerinde tespit edilen Fe oksitleyen bakteri türleri, reaksiyon 2'nin gerçekleşmesinde mikroorganizmaların etkili olduğunu önermektedir (Çizelge 6). Fe(II)'yi oksitleyerek $\mathrm{Fe}$ oksi-hidroksitlerin oluşumuna neden olan bu mikrooganizmalar, Balya atı sahasında metallerin sedimanlarda depolanmasinı kontrol etmektedirler. Asidik su sedimanlarında yapılan XRD çalışmalarında, jarosit, plumbojarosit ve götit gibi Fe oksit mineralleri tespit edilmiştir. Bunun yanı sıra, aynı örnekte Fe'li ikincil mineral oluşumları da saptanmıştır (Çizelge 3). Bunlara ek olarak Fe oksitlerce zengin sediman örneklerinin metal içeriklerinin, özellikle As ve $\mathrm{Cu}$, oldukça yüksek olması atıklardan salınan metallerin Fe-oksihidroksitlerde tutunduğunu göstermektedir (Çizelge 1). Fe'ce zengin çökellerde baz metal zenginleşmesi $\mathrm{Cu}, \mathrm{Zn}$, As ve $\mathrm{Pb}$ gibi metallerin oksit yüzeylerine olan tutunma isteğiyle uyumludur (Dzombak ve Morel,1990; Bigham ve Nordstrom, 2000). Asidik koşullarda $(\mathrm{pH}<3)$ baz metallerin $\mathrm{Fe}$ oksihidroksitlerin yüzeyine etkili bir şekilde tutunması farklı AMD oluşumlarında da saptanmıştır (Schemel vd., 2000). Balya Atık sahasında Çinko ve bakırla 'la karşılaştırıldığında kurşunun suya oranla sedimanlarda zenginleşmesini denetleyen diğer önemli bir faktör anglezit oluşumudur (Çizelge 1 ve 5). Düşük çözünürlüklü anglezit Pb'nun taşınmasını engelleyerek sedimanda birikmesine neden olmaktadır. Asidik sedimalarda tespit edilen anglezit oluşumu bununla uyumludur (Çizelge 2). 
Balya Atık sahasinda metallerin sedimanlarda depolanmasinı kontrol eden diğer önemli bir faktör ise mikrobiyal Fe(III) indirgenmesidir. Atıkların Maden deresine ulaştı̆̆1 kesimlerde (MDS1-3) Rhodoferax ferrireducens T118, Ferribacterium limneticum ve Geobacter gibi anaerobik fakültatif Fe(III) aq indirgeyen mikroorganizmaların tespit edilmesi, Fe oksidasyonunun yanı sira Fe(III) indirgenmesinin de sahada aktif olduğunu ortaya koymuştur. $\mathrm{Fe}$ oksihidroksitlerin çözünmesini sağlayan bu bakteriler çözünme işlemleri sırasında $\mathrm{Fe}$ oksihidroksitlere tutunan metallerin tekrar serbest kalmasina neden olmaktadır. Balya atı sahasında Fe oksidasyonu ve indirgenmesi şeklinde tespit edilen mikrobiyal $\mathrm{Fe}$ döngüsü atıklardan metallerin çözünmesinde (reaksiyon $1,3,4,5,6)$ taşınmasında ve depolanmasında etkili biyojeokimyasal reaksiyonlardır.

\section{SONUÇLAR}

Balya maden atıklarının çevresinde oluşan asidik suların metal içerikleri ile atıkların metal içerikleri arasındaki benzerlik, metal kaynağı olarak atıkları göstermektedir. Özellikle atıkların içerdikleri cevher mineralleri bu metallerin ana kaynağıdır. Atıklarda ve atıkların çevresinde oluşan asidik su, sediman ile atıkların Maden Deresine ulaştığı kesimlerde moleküler ekoloji teknikleri kullanılarak yapılan çalışmayla sahada kemoototrofik temelli bir mikrobiyal topluluğun geliştiği ortaya konmuştur. Ağırlıklı olarak aSOB ve aFeOB mikroorganizmalardan oluşan bu topluluk Balya $\mathrm{Pb}-\mathrm{Zn}$ maden atıklarında ki sülfürlü ve Fe'li cevher minerallerini reaksiyon 1-9'da gösterildiği gibi ayrıştırarak ortama asit ve metal salınımına neden olmaktadır. Atık sahasında piritik kükürtün sülfata oksitlenmesinde kemolitoototrofik bakteri türlerinden hem Acidithiobacillus spp. hem de Thiobacillus spp sülfür oksitleyen bakteri türleri rol almaktadır. Atmosferik $\mathrm{CO}_{2}$ 'i karbon kaynağı piriti ise enerji kaynağ1 olarak kullanan bu mikroorganizmalar piritik kükürt ve $\mathrm{Fe}(\mathrm{II})$ 'yi oksitleyerek piritin çözünmesine neden olmaktadırlar. Sahada tespit edilen aFeOB'lerin sahada tespit edilen $\mathrm{Pb}, \mathrm{As}, \mathrm{Cu}$ ve Fe içeren ikincil minerallerin oluşumunda ve dolayısıyla söz konusu bu metallerin taşınımında etkili oldukları ortaya konmuştur.

\section{KATKI BELIRTME}

Bu Çalışma, TÜBİTAK-ÇAYDAG tarafından desteklenen 108Y177 no'lu proje kapsamında gerçekleştirilmiştir. Yazarlar desteklerinden dolayı TÜBİTAK'a teşekkürlerini sunarlar.

\section{EXTENDED SUMMARY}

Oxidation of sulfide minerals such as pyrite at Earth's surface condition result in formation of higly acidic, sulfate rich water known as acidic drainage. Acid drainage formation is accelareted with the extraction and processing of sulfide ore deposits . During the mining activities large volume of sulfide bearing materials with large surface area are produced and exposed to atmospheric conditions. Oxidation of these sulfide rich wastes generate solutions rich in toxic-heavy metals known as acid mine drainage (AMD). AMD can be generated by chemical and biological oxidation of pyrite, and other metal sulfides in mine waste heaps or in tailings from sulfidic ore processing. Recen studies have shown that a diverse microbial population is present in AMD sites that were previously thought voided of life due to limited nutrients and extreme living conditions. A chemo-autotrophically-based biosphere formed by archea and bacteria largely responsible for the oxidation of sulfide minerals have been identified in these extreme environments. Microbial activity 
can accelerate dissolution of pyrite, arsenopyrite, chalcopyrite, galena and sphalerite causing the release of toxic metals such as $\mathrm{As}, \mathrm{Pb}, \mathrm{Cu}$ and $\mathrm{Zn}$ into the environment (Blowes vd., 1998; Benner $v d$., 2000 ). Particularly the numerous species of genera Thiobacillus, Acidithiobacillus, and Leptospirillum responsible for the oxidation of sulfide and iron minerals have been determined in AMD sites (Nordstrom ve Southam, 1997; Brett ve Banfield,2003). Therefore, in order to develop an efficient remediation strategies to prevent AMD formation, it is crucial to identify microbial community and their role during oxidation of sulfide minerals .

Balıkesir -Balya Pb-Zn deposits was mined between 1880 and 1940. After the long inactive period the recent mining operations is underway in the field. Balya Pb-Zn Mine tailings site, the oldest and largest waste site of Turkey, contain approximately 1.5 million ton waste rocks such as flotation tailings, slag from the smelter operation and insignificant amount of jig wastes. These WR are randomly deposited along the Maden Creek and left to atmospheric conditions without any prevention (Fig.1). In this study, biogeochemical characteristsics of Balıkesir-Balya $\mathrm{Pb}-\mathrm{Zn}$ mine tailing site and its influences on generation of AMD was investigated by geochemical, molecular and microbiological approaches. Water, sediment and mine tailing samples were collected and physicochemical characteristics (e.g. pH, Eh and temperature) of water samples were determined in situ by using WTW probe.

The oxidation of sulfide rich rocks and wastes, mostly left over from Balya Pb-Zn mining activities, is generating acidic water with low $\mathrm{pH}$ (2.7), and high metals containing up to 1.88 $\mathrm{mg} / \mathrm{L} \mathrm{Pb}, 24 \mathrm{mg} / \mathrm{L} \mathrm{Zn,} 2.5 \mathrm{mg} / \mathrm{L}$ As ve $17 \mathrm{mg} / \mathrm{L}$ $\mathrm{Cu}$ (Tables 4 and 5). An inverse correlation between $\mathrm{pH}$ and metal concentrations is evident in all water samples from acidic and surface water. Among all waters sampled, acidic waters from acidic ponds have the lowest $\mathrm{pH}$ (2.7) and highest concentrations of $\mathrm{Cu}, \mathrm{Pb}, \mathrm{Zn}, \mathrm{As}$, which result from oxidation of sulfide-rich waste in the mine tailings. Geochemical and molecular/ microbiological analysis on mine waste, sediment and water samples (acidic, surface) show that acidic surface waters generated from sulfide weathering are principal pathways for mobility and redistribution of environmentally important elements into the environments. Total living microorganims responsible for $S$ and Fe cycles in the tailings site were determined by using the most probably number method (MPN). For this culture based method, the acidic water and sediments from the acidic ponds and surface water collected from Maden Creek were used. The mean acidofilic sulfur oxidizing bacteria (aSOB) and acidophilic iron oxidizing bacteria were determined as $8.4 \times 10^{8} \mathrm{cell} / \mathrm{ml}$ ve $9.6 \times 10^{7} \mathrm{cell} / \mathrm{ml}$, respectively. The relatively low values for surface water of Maden creek, where mine wastes reach, were determined as $3.8 \times 10^{6} \mathrm{cell} / \mathrm{ml}$ ve $5.7 \times 10^{3} \mathrm{cell} / \mathrm{ml}$, respectively (Table 4). Total microorganims were determined by using 16SrDNA molecular methods. Molecular analysis of $16 \mathrm{~S}$ rDNA gene sequences from acidic sediment and sediment from Maden Creek show the dominance of $S$ and Fe-oxidizing prokaryotes belonging to Acidithiobacillus spp. genus in the primary drainage communities. Acidithiobacillus ferrooxidans and Acidithiobacillus thiooxidans, the two sulfur-oxidizing species most commonly isolated from acidic drainage waters, are widely considered to be significant contributors to AMD generation. Relatively small populations of Sulfobacillus spp.were also determined. Moreover, species belong to Thiobacillus spp.and Thiovirga spp. genus were only determined on the sediment samples from Maden creek with low acidity relative 
to acidic sediment (Table 6). Molecular biological and geochemical data suggest that $S$ and Fe cycles are regulated by a dynamic microbial population in the tailing site. Microbial pyrite oxidation is the main biogeochemical reactions controlling acid production in the field. Acid leaching and microbial oxidation of galena and sphalerite is the main source of toxic metals released into the environment. Also, identification of $\mathrm{Fe}$ oxidizer and reducer along with Fe-oxides (e.g.Jarosite, plumbojarosite and goethite) in the sediments of acidic ponds indicate significance of microbial $\mathrm{Fe}$ cycle governing mobilization and redistribution of the metals in the tailings site.

\section{DEĞINIILEN BELGELER}

Agdemir, N., Kırıkoglu, S., Lehmann, B. ve Tietze. J., 1994. Petrology and alteration geochemistry of the epithermal Balya Pb-Zn-Ag deposits, NW Turkey. Miner Deposita, 29,366-371.

Akyol, Z., 1978. Balya Madeni ve Atıkları Sorunu, Yeryuvarı ve İnsan, Mayıs, 68-69

Akyol, Z., 1980. Balıkesir, Balya, Arı-Orta Sahası Pb-Zn-Cu Cevher Yatağı Maden Jeolojisi ve Rezerv Çalışmaları, MTA Rap. No 6973.

Akyol. Z., 1982. Balıkesir-Balya bölgesinin jeolojisi, mineralojisi ve maden potensiyeli). Earth Sci Rev 3(1-2),168-169.

Aygen, T., 1956.Balya bölgesinin jeolojisi .Bull Miner Res Expl Inst Turkey D/11.

Aykol, A., Orgun, Y., Budakoglu, M., Turhan, M., Gultekin, AH., Yavuz, F., Esenli, V., Kumral, M,. 2002. Heavy metal pollution in Kocadere River Balya Balikesir, Turkey (in Turkey (in Turkish). 55th Geological Congress of Turkey, pp 30-31.

Balcı, N., Bullen, T.D., Witte-Lien ,K., Shanks, W.C., Motelica, M. ve Mandernack, K. W.,2006. Iron isotope fractionation during microbially stimulated $\mathrm{Fe}$ (II) oxidation and $\mathrm{Fe}$ (III) precipitation. Geochimica et Cosmochimica Acta, 70(3), 622-639.

Balc1, N., W.C. Shanks, Mayer, B., ve Mandernack, K. W., 2007. Oxygen and Sulfur Isotope Systematics of Sulfate Produced by Bacterial and Abiotic Oxidation of Pyrite Geochim. Cosmochim. Acta, 622-639.

Balc1, N. C., 2010.Effect of bacterial activity on trace metals release from oxidation of sphalerite at low $\mathrm{pH}(<3)$ and implications for AMD environment. Earth and Environmental Sciences. 60,485-493.

Balcı, N., Mayer, B, Shanks, W. C., ve Mandernack, K. W., 2012. Oxygen and sulfur isotope systematics of sulfate produced during abiotic and bacterial oxidation of sphalerite and elemental sulfur. Geochimica et Cosmochimica Acta 77 335-351.

Benner, S.G., Gould, W.D.ve Blowes, D.W., 2000. Microbial populations associated with the generation and treatment of acid mine drainage. Chem. Geol. 169, 435-448.

Bigham, J.M. ve Nordstrom, D.K., 2000. Iron and aluminum hydroxysulfates from acid sulfate waters. In: Alpers, C.N.Jambor, J.L., Nordstrom, D.K. (Eds.), Sulfate Minerals Crystallography, Geochemistry, and Environmental Significance. Rev. Mineral. Geochem. 40, 351-403.

Blowes, D.W., Jambor, J.L., Hanton-Fong, C.J., Lortie, L.ve Gould, W.D., 1998. Geochemical, mineralogical and microbiological characterization of a sulphide-bearing carbonate-rich gold-mine tailings impoundment, Joutel, Québec. Appl. Geochem. 13, 687-705.

Bond, P., Druschel, G.K., ve Banfield ,J.F., 2000. Comparison of acid mine drainage microbial communities in physically and geochemically distinct ecosystems. Appl. Environ. Microbiol., 66,4962-4971.

Brett J. Baker ve Banfield, J. F.,2003. Microbial communities in acid mine drainage. FEMS Microbiology Ecology, 44 ( 2) 139-152.

Brett J. Baker ve Banfield, Jillian F., 2003.Microbial communities in acid mine drainage. FEMS Microbiology Ecology, 44( 2). pp. 139-152.

Brunner, B., Yu, J.-Y., Mielke, R.E., MacAskill, J.A.,Madzunkov, S., McGenity, T.J. ve Coleman, M., 2008. Different isotope and chemical patterns of pyrite oxidation related to lag and exponential growth phases of Acidithiobacillus ferrooxidans reveal a microbial growth

Cochran, W.G., 1950. Estimation of bacterial densities by means of the most probable number. Biometrics 6, 105-116.

Descostes M., Mercier F., Beaucaire C., Zuddas P., ve Trocellier P., 2001. Nature and distribution of chemical species on oxidized pyrite surface: Complementarity of XPS and nuclear microprobe analysis. Nucl. Inst. Methods Phys. Res. B.,181,603-609

Descostes, M., Vitorge, P.ve Beaucaire, C., 2004. Pyrite dissolution in acidic media. Geochim. Cosmochim. Acta 68, 45594569 .

Druschel, G.K., Baker, B.J., Gihring, T.H. ve Banfield, J.F., 2004. Acid mine drainage biogeochemistry at Iron Mountain, California. Geochemical Transactions 5 (2), 13-32. 
Edwards, K.J., Hu, B., Hamers, R.J. ve Banfield, J.F., 2001. A new look at microbial leaching patterns on sulfide minerals. FEMS Microbial Ecology, 34(3): 197-206

Dzombak, D.A.ve Morel, F.M.M., 1990. Surface Complexation Modeling: Hydrous Ferric Oxide. Wiley, New York.320

EPA (United States Environmental Protection Agency) http://water. epa.gov/scitech/swguidance/

Fowler, T.A., ve Crundwell, F.K.,1998. Leaching of zinc sulfide by Thiobacillus Ferrooxidans: Experiments with a controlled redox potential indicate no direct bacterial mechanism. Appl. Environ. Microbiol, 64, 3570-3575.

Garrels R. M. ve Thomson M. E., 1960. Oxidation of pyrite by iron sulfate solutions. Geochim. Cosmochim. Acta 68, 45594569.

Gaudette H., Flight W., Toner L. ve Folger D., 1974. An inexpensive titration method for the determination of organic carbon in recent sediments. J. Sediment. Petrol. 44, 249-253

Gleisner, M., Herbert, R. B., ve Kockum P. C. F., 2006. Pyrite oxidation by Acidithiobacillus ferrooxidans at various concentrations of dissolved oxygen. Chem. Geol. 225, 16-29.

Gould, W.D. ve Kapoor, A., 2003. The microbiology of acid mine drainage. In: Jambor,

J.L., Blowes, D.W., Ritchie, A.I.M. (Eds.), Environmental Aspects of Mine Wastes, Short Course Series, vol. 31. Mineralogical Association of Canada, Ottawa, 203-226.

Gould, W.D., McCready, R.G.L., Rajan, S., Krouse, H.R., 1989. Stable isotope composition drainage in the western United States. In: Alpers, C.N., Blowes, D.W. (Eds.), Environmental Geochemistry of Sulfide Oxidation. American Chemical Society.450

Gül, S., 2014. Balıkesir Balya Pb-Zn madeni atık sahasının biyojeokimyası ve asidik maden drenajı oluşumuna etkilerinin araştırılması . İTÜ Fen Bilimleri Enstitüsü., İstanbul, Yüksek Mühendislik Tezi, s.117.

Hulshof, A.H.M., Blowes, D.W. ve Gould, W.D., 2006. Evaluation of in situ layers for treatment of acid mine drainage: a field comparison. Water Res. 40, 1816-1826.

Johnson, D.B. ve Hallberg, K.B.,2003. The microbiology of acidic mine waters. Res Microbiol. 154(7), 466-473.

Kovenko V (1940) Balya lead mines (Turkey). Bull Miner Res Expl Inst Turkey 4/21:587-594

Moses, C.O. ve Nordstrom K., 1987. Aqueous pyrite oxidation by dissolved oxygen and by ferric iron. Geochimica et Cosmochimica Acta,51, 1561-1571.

MTA, 1984, Balya (Balıkesir) Kurşun-Çinko Cevher Yatağı Ön Fizibilite Çalışması
Nordstrom, D.K., Alpers, C.N., Ptacek, C.J. ve Blowes, D., 2000. Negative $\mathrm{pH}$ and extremely acidic mine waters from Iron Mountain, California. Environ. Sci. Technol, 34,254-258.

Nordstrom, D.K., ve Alpers, C.N., 1999. Geochemistry of Acid Mine Waters in, The Environmental Geochemistry of Mineral Deposits. G.S. Plumlee and M.J. Logsdon, eds. Rev. Econ. Geol. 6A, 133-160.

Nordstrom, D.K.ve Southam, G., 1997. Geomicrobiology of sulfide mineral oxidation. In: Banfield, J.F., Nealson, K.H.(Eds.), Geomicrobiology: Interactions between microbes and minerals. Rev. Mineral. 35, 361-390.

Öngür, T., 2003. Balya Çinko-Kurşun Madeni,Çevre Sorunları ve Toplumsal Yeniden Kalkınma. TMMOB .

Plumlee, G.S., 1999. The environmental geology of mineraldeposits. In: Plumlee, G.S., Logsdon, M.J. (Eds), TheEnvironmental Geochemistry of Mineral Deposits, Part A, Processes, Techniques, and Health Issues. Rev. Econ. Geol.6A, 71-116.

Randall, S.R., Sherman, D.M., Ragnarsdottir, K.V., 2001. Sorption of $\mathrm{As}(\mathrm{V})$ on green rust $(\mathrm{Fe} 4(\mathrm{II}) \mathrm{Fe}(\mathrm{II})(\mathrm{OH}) 12 \mathrm{SO} 4 \cdot 3 \mathrm{H} 2 \mathrm{O})$ and lepidocrocite $(\gamma-\mathrm{FeOOH})$ : surface complexes from EXAFS spectroscopy. Geochim. Cosmochim. Acta 65 (7), 1015-1023.

Rimstidt, J.ve Vaughan, D., 2003. Pyrite oxidation: a state-of-theart assessment of the reaction mechanism. Geochim. Cosmochim. Acta 67, 873-880.

Rimstidt,J.D; Chermak, J.A., ve Gagen, M.P. 1994.Rate of reaction of Galena,Sphalerite, Chalcopyrite and Arsenopyrite with $\mathrm{Fe}$ (III) in Acidic solutions, Environmental geochemistry of sulfide oxidation: Washington , D.C., American chemical society, symposium series 550, 2-14.

Sand W., Gehrke T., Jozsa P. G. ve Schippers A. 2001. (Bio)chemistry of bacterial leaching-direct vs. indirect bioleaching. Hydrometallurgy 59, 159-175.

Sasaki, K., Tsunekawa, M., Ohtsuka, T.ve Konno, H., 1995. Confirmation of a sulfur-rich layer on pyrite after oxidative dissolution by FeIII ions around $\mathrm{pH} 2$. Geochim. Cosmochim. Acta 59, 3155-3158.

Schemel, L.E., Kimball, B.A.ve Bencala, K.E., 2000. Colloidal formation and metal transport through two mixing zones affected by acid mine drainage near Silverton, Colorado. Appl. Geochem. 15, 1003-1018.

Schippers, A., Jozsa, P.G. ve Sand, W., 1996. Sulfur chemistry in bacterial leaching of pyrite. Appl. Environ. Microbiol, $62,3424-3431$

Schippers, A., Rohwerder, T. ve Sand, W., 1999. Intermediary sulfur compounds in pyrite sediments and soils. In: Amend, J.P., Edwards, K.J., Lyons, T.W. (Eds.), Sulfur Biogeochemistry - Past and Present. : Special Paper, 379. Geological Society of 
Schippers, A., Jozsa, P.-G., Sand, W., Kovacs, Z.M. ve Jelea, M., 2000. Microbiological pyrite oxidation in a mine tailings heap and its relevance to the death of vegetation. Geomicrobiol. J. 17, 151-162.

Schippers, A., 2004. Biogeochemistry of metal sulfide oxidation in mining environments, sediments and soils. In: Amend, J.P., Edwards, K.J., Lyons, T.W. (Eds.), Sulfur Biogeochemistry — Past and Present. : Special Paper, 379. Geological Society of America, Boulder, Colorado, USA, 49-62.

Schippers, A. ve Bosecker, K., 2005. Bioleaching: analysis of microbial communities dissolving metal sulfides. In: Barredo, J.-L. (Ed.), Methods in Biotechnology. Microbial Processes and Products, Vol. 18. Humana Press Inc, Totowa, New York, 412.

Silverman, M. P. ve Lundgren, D. G., 1959. Studies on the chemoautotrophic iron bacterium Ferrobacillus ferrooxidans. I. An improved medium and a harvesting procedure for securing high cell yields. J. Bacteriol. 77, 642-647.

Singer P. C. ve Stumm W., 1970. Acid mine drainage: The ratelimiting step. Science 167, 1121-1123.

Stumm ve Morgan, 1981. Aquatic chemistry: An introduction emphasizing chemical equilibria in natural waters. John Wiley and Sons, New York, 780s.

Suzuki, I. ve Chan, C. W., 1994.Oxidation of inorganic sulfur compounds by Thiobacilli. Environmental geochemistry of sulfide oxidation: Washington, D.C., American chemical society, symposium series 550, 61-67.
Suzuki, I., Chan, C. W.,1994. Oxidation of inorganic sulfur compounds by Thiobacilli. Environmental geochemistry of sulfide oxidation: Washington , D.C., American chemical society, symposium series 550, 61-67.

Sweerts, J. R. A., Beer, D. D., Nielsen, L. P., Verdouw, H., Heuvel, J. C. V. d., Cohen, Y. ve Cappenberg, T. E.,1990. Denitrification by sulphur oxidizing Beggiatoa spp. mats on freshwater sediments. Nature 344, 762-763.

Taylor, B., ve Wheeler, M.C.,1984b. Stable isotope geochemistry of acid mine drainage: experimental oxidation of pyrite . Geochimica and Cosmochimica Acta,48 : 2669-2678.

Taylor, B.E.ve Wheeler, M.C., 1994. Sulfur- and oxygen-isotope geochemistry of acid mine treatment of acid mine drainage: a field comparison. Water Res. 40, 1816-182

$\begin{array}{lcc}\text { Makale Geliş Tarihi } & : & 04.04 .2014 \\ \text { Kabul Tarihi } & : & 15.07 .2014 \\ & & \\ \text { Received } & : & 04.04 .2014 \\ \text { Accepted } & : & 15.07 .2014\end{array}$

